\title{
Tunceli Kentinin Nüfus Özellikleri
}

\section{Arş. Gör. Dr. Fethi Ahmet Canpolat ${ }^{*}$}

Gelis tarihi: 08.03.2019

Kabul tarihi: 14.03.2019

\section{Atıf bilgisi:}

Uluslararası Bilimsel Araștırmalar Dergisi (IBAD)

Cilt: 4 Sayı: 2

Sayfa: 183-200 Yıl: 2019

Dönem: Yaz

This article was checked by iThenticate. Similarity Index 05\%

${ }^{1}$ Firat Üniversitesi, Türkiye, facanpolat@,firat.edu.tr, ORCID ID 0000-0002-6084-7735

\footnotetext{
* Sorumlu yazar
}

ÖZ

Doğu Anadolu bölgesinin, Yukarı Frrat bölümünde yer alan Tunceli kenti, 26,7 $\mathrm{km}^{2}$ 'lik yüz ölçüme sahiptir. Nüfus bakımından 2017 yılı itibariyle 973 ilçe içinde 386. il merkezleri arasında ise 79. siradadır. 2004 yılında DPT tarafindan hazırlanan sosyo-ekonomik gelişmişlik araştırmasına göre 6 gruba ayrılan ilçeler içinde, gelişmişlik bakımından 2. grupta yer almaktadır. Kentin 1935 yılında kurulmasına karar verilmiş ve 1947 yılında valiliğinin Elazığ'dan buraya taşınmasıyla il merkezine dönüşmüştür. Çalışmada TÜIK'ten 1940-2018 yıllarına ait nüfus verilerine ulaşılmış, ayrıca kentte mahalle bazında değerlendirme yapabilmek için nüfus, eğitim, konut ve ekonomi gibi başl1klarda veriler talep edilerek değerlendirilmiştir. Kentteki nüfusun gelişimi durağan artış dönemi (1940-1960), dinamik artış dönemi (1960-1990) ve ikinci durağan artış dönemi (1990-2018) olarak belirtilebilir. Kentin en önemli problemi, nüfus tutma kapasitesinin düşük olmasıdır. Bu problemi azaltmak için 1968 yılından beri kalkınmada öncelikli bölge olarak kabul edilen il'de, il merkezi başta olmak üzere kamusal yatırımlar arttırılmaktadır. Tunceli'nin bir mahalle olarak baştan inşa edilmesinden, orta ölçekli bir kente dönüșme süreci, nüfusun değişimiyle doğrudan ilișkilidir. Ancak bu nüfusun değişimi ve bileşenleri üzerinde kentin konumu, sosyo-kültürel yapısı, tarihsel süreç içinde meydana gelen olaylar ve devletin müdahaleleri oldukça belirleyici olmuştur. Dolayısıyla Tunceli kenti hem yerleşme özellikleri açısından hem de demografik yapısı bakımından farklılaşan, kendine özgü bir karaktere sahiptir.

Anahtar Kelimeler: Tunceli, Nüfus, Göç, Sosyo-Ekonomik Yapı, Kent. 


\section{Population Characteristics of the City of Tunceli}

\section{Res. Asst. Dr. Fethi Ahmet Canpolat ${ }^{1^{*}}$}

First received: 08.03.2019

Accepted: 14.03.2019

\section{Citation:}

Journal of the International Scientific Research (IBAD)

Volume: 4 Issue: 2

Pages: 183-200 Year: 2019

Session: Summer

This article was checked by iThenticate. Similarity Index 05\%

${ }^{1}$ Firat University, Turkey, facanpolat@,firat.edu.tr, ORCID ID 0000-0002-6084-7735

* Corresponding Author

\begin{abstract}
Located in the Upper Euphrates region of the Eastern Anatolia region, the city of Tunceli has a surface area of $26.7 \mathrm{~km}^{2}$. As of 2017, it is 386 in 973 districts. It is 79th among the provincial centers. According to the socio-economic development survey prepared by the State Planning Organization in 2004, it is included in the second group in terms of development in the districts divided into 6 groups. The city was decided to be established in 1935 and the governorship was moved to Elazığ in 1947 and it became a city center. In the study, population data from TurkStat for the years 1940-2018 were reached. In addition, data on population, education, housing and economy have been evaluated in order to be able to evaluate the neighborhood in the city. The development of the population in the city can be defined as the period of stagnant increase (1940-1960), the period of dynamic increase (19601990) and the second stationary rise period (1990-2018). The most important problem of the city is the low population holding capacity. In order to reduce this problem, public investments have been increased in the province and the city, which have been accepted as the priority region in development since 1968. The process of being transformed into a middle-sized city from the beginning of its construction as a neighborhood in Tunceli is directly related to the change of population. However, the city's location, socio-cultural structure, the events that took place in the historical process and the interventions of the state were very determinant on the change and its components. Therefore, the city of Tunceli has a unique character, which is different in terms of its settlement characteristics and demographic structure.
\end{abstract}

Keywords: Tunceli, Population, Migration, Socio-Economic Structure, Urban. 


\section{GíRİş}

Nüfus coğrafyası; nüfusun büyüklüğünü, bileşimini, mekânsal dağılımını ve zaman içinde meydana gelen popülasyondaki değişimlerini araştırmaktadır. $\mathrm{Bu}$ araştırma nüfusun yapısının doğumlar, ölümler ve göçler yoluyla nasıl değiştiğini anlamaya çalışır. Söz konusu değişim, sosyal ve kültürel coğrafya, ulaşım coğrafyası, ekonomik coğrafya ve sağlık coğrafyasının yanı sıra diğer çalışma ve disiplinlerle de ilgilidir (Newbold, 2014:3, s. 258).

Demografik yapı ve bileşenlere ait bilgiler sağlık, eğitim ve ulaşım gibi kamusal yatırımlarda, pazarlamada ve politikada etkin bir şekilde kullanılmaktadır (Newbold, 2014, s. 258-261). Örneğin günümüzde kurumsal firmalar bir işletme açmadan önce cadde-sokak ölçeğinde nüfus bilgilerini(yaş grubu, cinsiyet, eğitim, gelir seviyesi vb.) incelemeden karar almamaktadır.

Yerleşmelerin idari taksimattaki yeri, genellikle tarihsel geçmişi ve nüfus büyüklükleri üzerinden belirlenir. Ancak bu çalışmada 20.yy'ın başına kadar herhangi bir yerleşmenin bulunmadığı bir alanda, yönetsel müdahalelerle ortaya çıkarılan Tunceli kentinin, nüfus özellikleri ele alınmıştır. Bu kent kurulduğu dönem itibariyle diğer il merkezleriyle karşılaştırıldığında bir köy görünümünde olan, zamanla kasabaya evrilen ve kent formuna ulaşan bir yerleşmedir. Dolayısıyla hem nüfusun gelişim seyri hem de kentsel gelişim süreci açısından dikkati çekmektedir.

Tunceli kenti kuzey kesiminde batıdan doğuya doğru Halil Tepe (1131 m), Dündül Tepe, Cer Tepe (1298 m), Ayı Tepe, Kesik Tepe ve Kireç Tepe(1099 m) ile; batı kesiminde ise kuzeyden güneye doğru Bozkaya Tepe, Kurusopa Tepe ve Rabat deresi ile; doğusunda Munzur suyu ile Pülümür çayının birleşerek oluşturduğu Munzur çayı üzerinde kurulu olan Uzunçayır Baraj Gölü'nün ${ }^{1}$ suları ile çevrilidir. Doğu kesiminde yalnızca Batman köyü sınırları içinde inşa edilen toplu konutlar yer almaktadır. Zamanla bu köyün kent bünyesine dâhil olacağı söylenebilir. Kentin yerleşme alanı yaklaşık olarak $26,7 \mathrm{~km}^{2}$, dir (Şekil 1).

Oldukça eğimli dağların ve ırmakların çevrelediği kent Munzur suyu vadisi üzerinden Ovacık ilçesine, Pülümür çayı vadisi üzerinden ise Erzincan ve Erzurum'a bağlanmaktadır. Bu iki ırmağın şehir merkezine yakın bir konumda birleşmesiyle Munzur çayı ortaya çıkmaktadır. Munzur çayının açmış olduğu vadi üzerinden ise Elazığ kentine Kovancılar ilçesinden bağlanan D-885 karayolu geçmektedir. Munzur çayı vadisi günümüzde Uzunçayır Baraj Gölü suları altında kalmıştır. Bu yollardan iller arası en önemli bağlantı aksı D-855 karayolu kuzeyden Erzincan $(120 \mathrm{~km})$, güneyden de Elazlğ kentlerine bağlanmaktadır. Etki sahasında bulunduğu Elazığ kentiyle bağlantısı, iki ana güzergâh üzerinden gerçekleşmektedir. Bunlardan ilki Pertek ilçe merkezine ulaştıktan sonra Keban Baraj Gölü üzerinden feribotlarla gerçekleşen $83 \mathrm{~km}$ uzunluğundaki yol, ikincisi ise Tunceli'den Elazı̆g'ın Kovancılar ilçesine ve buradan Elazığ'a bağlanan 140 km'lik yoldur. Kentte demiryolu hattı ve havaalanı mevcut değildir. Karayolu ulaşımı ise engebeli arazi nedeniyle zordur. Mevcut ulaşım problemlerine bağlı olarak ortaya çıkan izole yapı, kentin gelişimini yavaşlatmıştır (Şekil 1).

Tunceli'nin ayrı bir il olarak kurulmasından sonra, Tunceli kentinin kuruluş yeri olarak, o sırada hiç yerleşme olmayan boş bir alan seçilmiştir. Bu alan yerleşime çok elverişli değildir. Kent çevresi tepelik alanlarla çevrili Munzur suyu ve kollarının oluşturduğu drenaj ağı üzerindeki basamaklı düzlükler, taraçalar ve yamaçlarda yer almaktadır. Dolayısıyla Erzincan-Tunceli (D-885) çevre yolu dışındaki yollar dar ve kısa yollardan oluşmaktadır. Bu yollar genellikle eğim değeri fazla olan yollardır. Kentin jeomorfolojik özellikleri konutların yapısal özelliklerine, yerleşme dokusuna, merkezi iş sahasına, gelişim akslarına da belirgin bir şekilde yansımıştır. Aynı zamanda kentin doğal ortam özelliklerine bağlı olarak yapılaşma yasağı olan alanlar da mevcuttur. Bu alanlar arasında şehrin kuzeye doğru gelişimini engelleyen Döndül Tepe ve Zeytin Tepe eteklerinde sağanak yağışların etkisiyle kaya düşmesi riskine bağlı, Munzur suyunun güney sahili boyunca taşkın riskine bağlı; Esentepe, Cumhuriyet ve Alibaba mahallelerinde ise kaya düşmesi ve heyelan riskine bağl1 yapılaşmanın yasak olduğu alanlar mevcuttur.

\footnotetext{
${ }^{1}$ Uzunçayır Barajı Munzur suyu ve Pülümür çayının birleştiği yerden 17 km güneyde, 1993-2003 yılları arasında inşa edilmiş ve 2009 yılında su tutulmaya başlanmıştır. Kurulu gücü 84 MW olup yıllık ortalama üretimi 330 milyon kWh'tır. Normal su kotunda göl alanı $13,4 \mathrm{~km}^{2}$ dir.
} 
Devlet Planlama Teşkilatı tarafından başlatılan 1968 yılında Program Kararnamesi (Strateji ve Bütçe Başkanlığı, 2018) ile kalkınmada öncelikli yöreler kapsamına alınan Tunceli ili ve kenti daha sonra çıkarılan $18^{\prime}$ den fazla kararnamenin hepsinde yer almasına rağmen dikkate değer bir gelişme göstermemiştir.

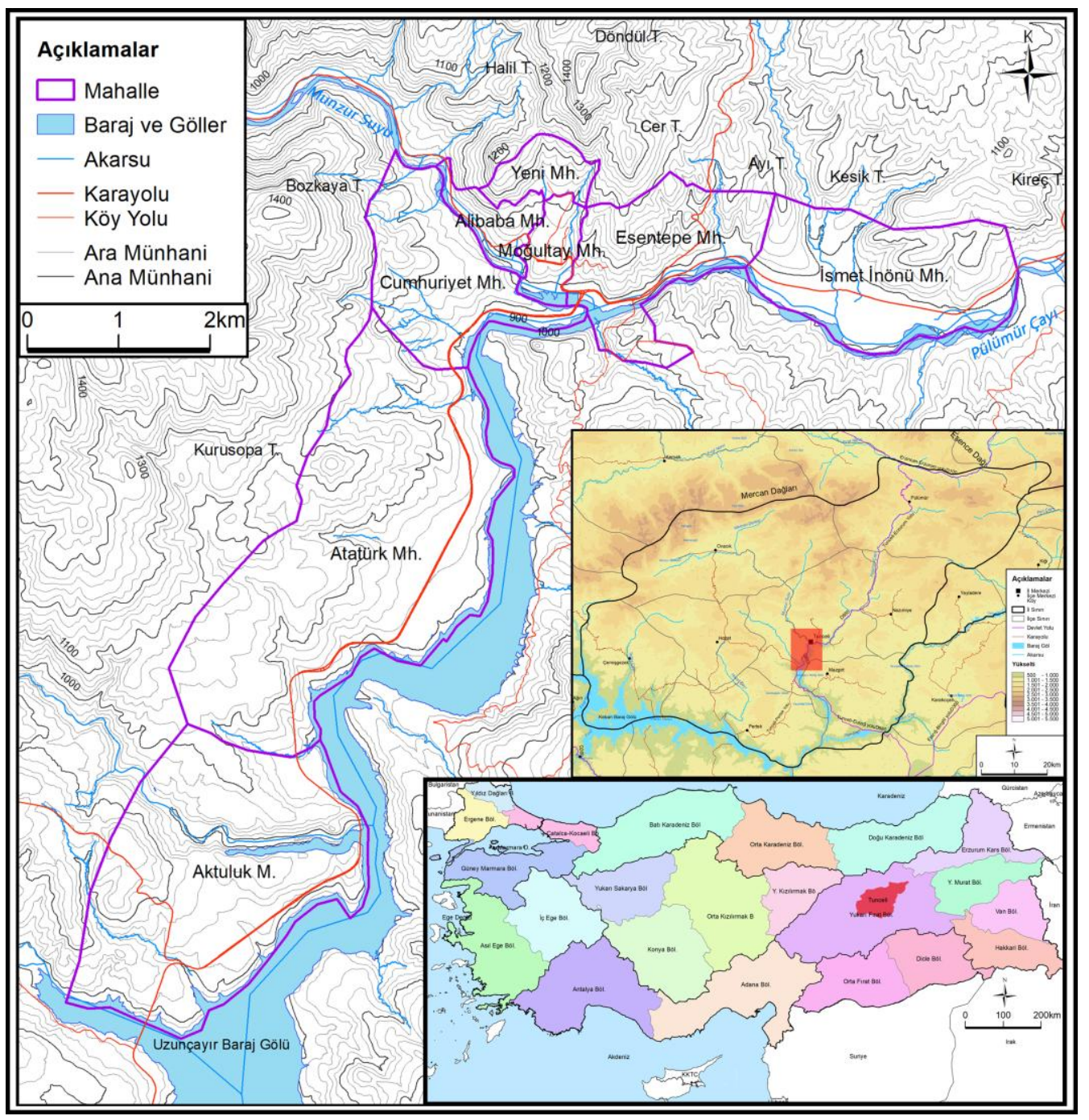

Şekil 1. Tunceli Kentinin Lokasyon Haritas1

Türkiye'de kentleşme politikalarından çıkarılan yasalardan ve uygulamalardan hareketle Rodwin'in (1964'ten aktaran Towfighi, 1970, s. 42) merkeziyetçi yaygınlaştırma politikasını takip ettiği söylenebilir. Buna göre ekonomik ve toplumsal kalkınmada kentleşmeden yararlanmayı olanaklı kılacak çekim veya büyüme merkezleri oluşturma düşüncesi kentlerin önemini daha da arttırmıştır. Bu kapsamda Tunceli kenti de Türkiye'deki diğer küçük ve orta ölçekli kentler gibi kentsel fonksiyonların etkisinin ve öneminin arttırılmaya çalışıldığı kentler arasında olduğu belirtilebilir. Dolayısıyla kentleşmeye bağlı değişim, Tunceli'de kentsel nüfus üzerinde de değişime neden olmaktadir.

\section{AMAÇ VE YÖNTEM}

Çalışma Tunceli kenti nüfusunun temel değişkenlerini ve bunlardaki değişimi analiz etmeyi amaçlamaktadır. Bu kapsamda TÜİK’ten 1940-2018 yıllarına ait nüfus verilerine ulaşılmış, ayrıca kentte mahalle bazında değerlendirme yapabilmek için nüfus, eğitim, konut ve ekonomi gibi başlıklarda veriler talep edilerek metin içinde analiz edilmiştir. Nüfusun dağılışı ve kentin genel durumunu anlayabilmek için Tunceli Belediyesinden İmar Planı açıklama raporu, Tunceli Belediyesi ve diğer resmi kuruluşlardan brifing raporlarına ulaşılmıştır. Zamansal ölçek açısından 1940-2018 yılları arasındaki süreç değerlendirilmeye çalışılmıştır. 
Araştırmanın sınırlılıkları arasında nüfus hareketleri konusu içinde kente yönelik verilerin bulunmaması, bazı başlıklarda bulunan verinin tarihinin yalnızca yakın ve kısa bir zaman dilimini kapsaması, sosyo-ekonomik yapıda kent nüfusunun iktisadi faaliyetlere dağılışına yönelik güncel bir verinin bulunamayışı yer almaktadır.

Tunceli'nin bir Cumhuriyet dönemi kenti olması, ilk kuruluş yerinde daha önce herhangi bir yerleşmenin olmaması, kuruluşundan günümüze kentin büyümesi üzerinde yönetsel kararların oldukça belirleyici olması, son yıllarda kamusal yatırımların artmasıyla birlikte mekânsal büyümenin arttığı bir kent olması araştırma alanı olarak seçilmesinde belirleyici olmuştur. Genellikle Tunceli ilini kapsayan bilimsel çalışmaların kenti açıklamada ve değerlendirmede yetersiz kalması, kent özelinde böyle bir çalışmanın yapılmasını teşvik etmiştir.

Çalışma nüfusun temel bileşenlerinin kent ölçeğinde resmi istatistik, yapılandırılmamış kısa mülakatlar ve arazi gözlemleriyle birlikte sentezlenmesi şeklinde bir yol izlemektedir. Bu kapsamda verilerin düzenlenmesi, tablolara ve tematik haritalara dönüştürülmesiyle konular somutlaştırılmaya çalışılmıştır.

\section{BULGULAR}

\section{Nüfusun Gelișimi}

Şehirler yaşamlarını sürdürebilmek ve beslenebilmek için yakınlarındaki kırsal alanlara ihtiyaç duydukları gibi sınırlarının ötesindeki alana da çeşitli hizmetleri sunarak bulundukları alanın mübadele merkezleri niteliğindedirler. Bu durum özellikle orta büyüklükteki şehirler için ayrı bir öneme sahiptir (Timor, 1997, s. 99). Buna göre Tunceli kentinin etki sahasının kısıtlı olmasının yanında, kırsal kesimindeki nüfusun da azalması kentteki nüfusun gelişimine olumsuz yansımaktadır.

Tunceli'de genel nüfus yapısı üzerinde, doğal ortam özelliklerinden kaynaklı değişkenler önemli bir role sahip gözükmektedir. Nitekim nüfusun gelişiminde, göçlerde, sosyo-ekonomik yapıda ve kültürel özelliklerde bunun etkilerini görmek mümkündür.

Günümüzdeki Tunceli şehrinin kurulduğu mevki, Osmanlı Devleti döneminde Erzurum eyaletinin Dersim sancağına bağlı Mazgirt kazası sınırları içinde bulunuyordu. 1877 isyanından sonra Dersim sancağı Erzurum'dan alınarak merkezi Hozat olan bağımsız bir vilâyet durumuna getirildi... 18791886 (bazı yayınlarda 1880-1888) yıllarını kapsayan bu dönemden sonra Dersim tekrar sancak durumuna getirilip Ma'mûretülazîz vilâyetine bağlandı. Millî Mücadele yıllarındaki Koçgiri isyanı (yörenin dışında olmasına rağmen), 1925'teki Şeyh Said isyanı ve 1930'lu yıllarda patlak veren bazı isyanlar güvenliği sağlamak için yeni bir vilâyetin kurulmasını gündeme getirdi ve 25 Aralık 1935 'te Tunceli Vilâyeti Kuruluş Kanunu kabul edildi. Korgeneral rütbesinde bir askeri vali tayin edildi. Fakat valinin oturacağ 1 vilâyet merkezi yoktu; bu sebeple yeni bir şehrin temelleri atıldı. Önceleri bu yerleşmeye bir aşiretin adından hareketle Kalan denildi. Kalan'ın inşası devam ederken vali komşu ilin merkezi Elaziz'de oturdu. 1 Ocak 1947 tarihinden itibaren vali, Tunceli'nin merkezi Kalan'ın inşası tamamlandığından buraya geçti (Tuncel, 2012, s. 379). 3223 sayılı kanun ile kurulmuş Kalan kasabasının adı, 1952 yılında, 1580 sayılı kanunun 9. maddesine göre Tunceli olarak değiştirilmiştir (Şaşmaz, 2014, s.260).

Tunceli kentinde nüfusun gelişimini, sayım dönemleri itibariyle 3 dönemde ele almak mümkündür. Bunlar 1940-1960 durağan artış dönemi, 1960-1990 dinamik artış dönemi, 1990 günümüz ise ikinci durağan artış dönemidir. Kuruluş döneminde Tunceli ilinin merkez ilçesi Kalan olarak geçmektedir. 1935-1947 yılları arasında kuruluşu gerçekleştirilen bu yeni yerleşme, başlangıçta tek bir mahalleden (Mameki Mahallesi) ibarettir ve 1940-1945 sayımlarında nüfusu 1000'in altındadır. Bu mahalle günümüzde Alibaba Mahallesi olarak geçmektedir. 1950'den sonra ise bugünkü Moğultay ve Atatürk Mahallelerinden geçen karayolu güzergâhı üzerinde yeni yerleşmeler oluşmuştur. 1960 yılına kadar Munzur nehrinin kuzey kesimi boyunca iki mahalleden oluşurken nüfus henüz 4 bin civarındadır (Tablo 1, Şekil 2). 
Tablo 1. Tunceli Kentinde Dönemlere Göre Mahalleler

\begin{tabular}{lcl}
\hline Tarih & $\begin{array}{c}\text { Mahalle } \\
\text { Sayısı }\end{array}$ & Mahalleler \\
\hline $1935-1949$ & 1 & Mameki \\
\hline $1949-1960$ & 3 & Mameki, Siğank, Alpdoğan (Moğultay) \\
\hline $1960-1975$ & 6 & $\begin{array}{l}\text { Alibaba (Mameki ve Siğank), Alpdoğan (Moğultay), Cumhuriyet, Yeni, } \\
\text { Esentepe, Atatürk }\end{array}$ \\
\hline $1975-2017$ & 8 & Alibaba, Moğultay, Cumhuriyet, Yeni, Esentepe, Atatürk, İsmet İnönü, Aktuluk
\end{tabular}

Kaynak: Tuncel, 2012, s. 379, Tunceli Belediyesi

1960-1990 arasında nüfus önceki döneme göre daha hızlı bir artış sürecine girmiştir. Bu büyüme süreciyle birlikte Munzur çayının güney kesimine doğru sıçrayan yerleşmede nüfus; 1975 yılında 10 bin, 1990 yılında ise 20 bin kişinin üzerine çıkmış ve 30 y1llık bir süreçte, yaklaşık 5 kat artış göstermiştir. 1970'lere kadar şehir merkezi silik bir yapıda iken, bu kesimdeki yapılaşmaların artması ile merkezi iş alanı ortaya çıkmaya başlamıştır.

1960-1975 döneminde kentin büyümesiyle Cumhuriyet, Yeni, Esentepe ve Atatürk mahalleleri ortaya çıkmıştır. 1990 yılından sonra il genelinde güvenlikle ilgili yaşanan problemlerden dolayı il dışına göç olayları artarak, nüfus artışında belirgin bir duraklama yaşanmıştır. Nitekim 1990-2017 yılları arasındaki 28 yıllık dönemde nüfus 24 binden 33 bin'e yükselmiştir. Bu dönemde kentin büyüme istikametinde yer alan Aktuluk köyü mahalleye dönüştürülerek belediye sınırlarına dâhil edilmiştir.

Tablo 2. Tunceli Şehrinde Nüfusun Gelişimi, Cinsiyet Oranları ve Nüfus Artış Oranları ile Tunceli Kentinin İl Nüfusuna Oranı

\begin{tabular}{|c|c|c|c|c|c|c|c|c|}
\hline \multicolumn{5}{|c|}{ Tunceli Kenti } & \multicolumn{2}{|c|}{ Nüfus Artış Oranı } & \multirow{2}{*}{ İl Nüfusu } & \multirow{2}{*}{$\begin{array}{c}\text { Kentin İl } \\
\text { Nüfusuna Oranı }\end{array}$} \\
\hline Yillar & Erkek & Kadın & Toplam & Cinsiyet Orant & Dönemler & Tunceli Kenti & & \\
\hline 1940 & 614 & 223 & 837 & 275 & - & - & 94639 & 1 \\
\hline 1945 & 558 & 204 & 762 & 274 & $1940-1945$ & $-8,96$ & 90446 & 1 \\
\hline 1950 & 1223 & 660 & 1883 & 185 & 1945-1950 & 147,11 & 105759 & 2 \\
\hline 1955 & 1385 & 975 & 2360 & 142 & $1950-1955$ & 25,33 & 121743 & 2 \\
\hline 1960 & 2349 & 1469 & 3818 & 160 & $1955-1960$ & 61,78 & 140068 & 3 \\
\hline 1965 & 3644 & 2181 & 5825 & 167 & $1960-1965$ & 52,57 & 154175 & 4 \\
\hline 1970 & 5187 & 4179 & 9366 & 124 & $1965-1970$ & 60,79 & 157293 & 6 \\
\hline 1975 & 6801 & 4836 & 11637 & 141 & $1970-1975$ & 24,25 & 164591 & 7 \\
\hline 1980 & 7146 & 5713 & 12859 & 125 & 1975-1980 & 10,50 & 157974 & 8 \\
\hline 1985 & 10302 & 8169 & 18471 & 126 & $1980-1985$ & 43,64 & 151906 & 12 \\
\hline 1990 & 13789 & 10724 & 24513 & 129 & 1985-1990 & 32,71 & 133143 & 18 \\
\hline 2000 & 14698 & 10343 & 25041 & 142 & $1990-2000$ & 2,15 & 93584 & 27 \\
\hline 2007 & 15374 & 11717 & 27091 & 131 & $2000-2007$ & 8,19 & 84022 & 32 \\
\hline 2008 & 17139 & 11447 & 28586 & 150 & $2007-2008$ & 5,52 & 86449 & 33 \\
\hline 2009 & 20011 & 11588 & 31599 & 173 & 2008-2009 & 10,54 & 83061 & 38 \\
\hline 2010 & 14194 & 12216 & 26410 & 116 & 2009-2010 & $-16,42$ & 76699 & 34 \\
\hline 2011 & 20244 & 12571 & 32815 & 161 & $2010-2011$ & 24,25 & 85062 & 39 \\
\hline 2012 & 18546 & 12923 & 31469 & 144 & 2011-2012 & $-4,10$ & 86276 & 36 \\
\hline 2013 & 17092 & 13955 & 31047 & 122 & $2012-2013$ & $-1,34$ & 85428 & 36 \\
\hline 2014 & 18123 & 15147 & 33270 & 120 & 2013-2014 & 7,16 & 86527 & 38 \\
\hline 2015 & 18969 & 15492 & 34461 & 122 & 2014-2015 & 3,58 & 86076 & 40 \\
\hline 2016 & 17613 & 15245 & 32858 & 116 & $2015-2016$ & $-4,65$ & 82193 & 40 \\
\hline 2017 & 17819 & 15227 & 33046 & 117 & 2016-2017 & 0,57 & 82498 & 40 \\
\hline 2018 & 17970 & 15545 & 33515 & 116 & 2017-2018 & 1,42 & 88198 & 38 \\
\hline
\end{tabular}

Kaynak: TÜIK, Genel Nüfus Sayımları (1940-2000), Nüfus İstatistikleri (2007-2017) 


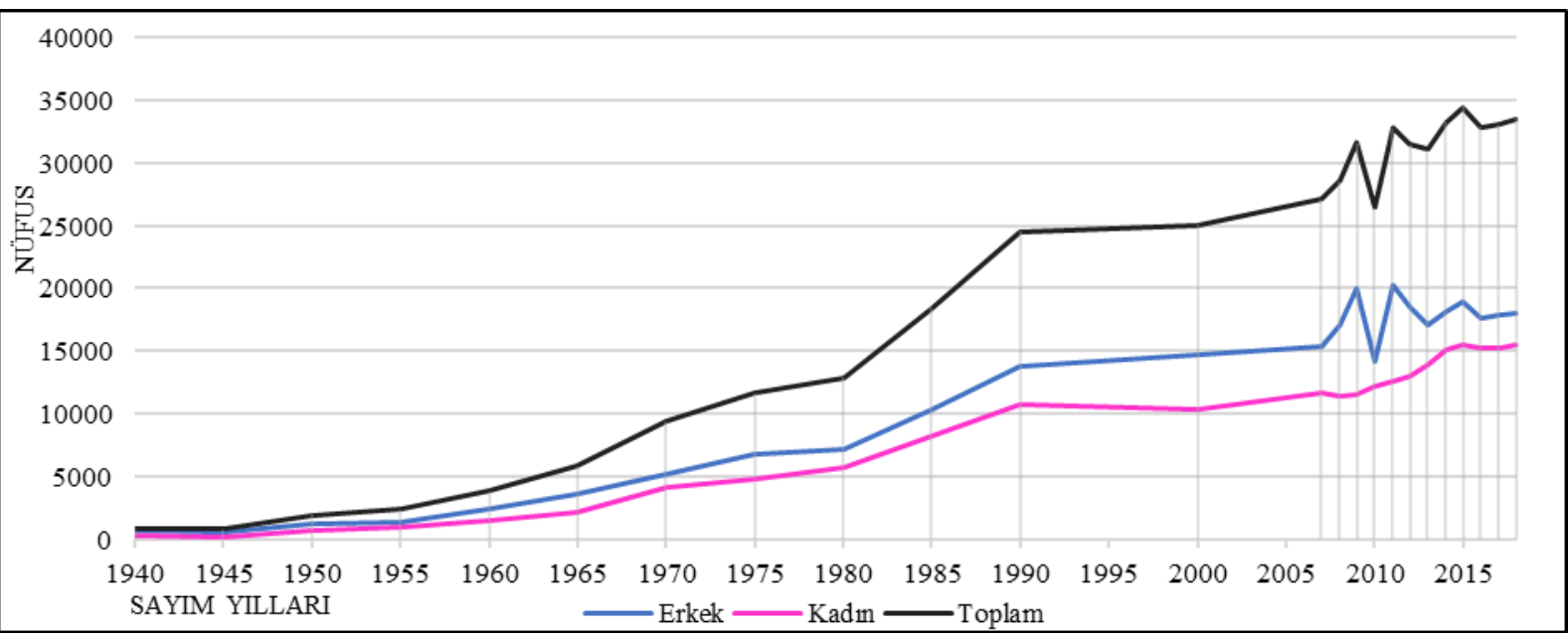

Şekil 2. Tunceli Şehrinde Nüfusun Gelişim (1927-2018)

Nüfus artış oranı bakımından Tunceli'de 1990'lı yıllara kadar Türkiye geneli kentlerinden daha yüksek bir yapı gösterirken, 1990'lı yıllardan sonra ise genel olarak daha düşük ve bazen negatif artış oranları görülmektedir. Ancak son yıllarda yapılan kamusal yatırımlarla ve toplu konut projeleriyle kent nüfus bakımından tekrar hareketlenmeye başlamıştır. Özellikle Munzur Üniversitesi, Organize Sanayi Bölgesindeki gelişmeler ile il geneli ve kente yönelik kamusal yatırımlar nüfus artışını pozitif yönde etkilediği söylenebilir (Tablo 2).

Tunceli'nin cinsiyet oranı bakımından değişimi ve güncel durumu da sıra dişı bir görünüm sergilemektedir. Kuruluş döneminde 275 olan cinsiyet oranı her zaman sahadaki erkek nüfusun fazlalığı nedeniyle 100'ün çok üzerinde seyretmiştir. Süreç içinde belirgin iniş ve çıkışların olduğu bu oran üzerinde ve nüfus sayısında, kentteki güvenlik görevlisi sayısı belirleyici olmuştur. Örneğin 2010 yılında erkek nüfusta, 5817 kişilik azalmanın çok büyük bir bölümü kentteki güvenlik görevlisi sayısında yaşanan değişiklikten kaynaklanmaktadır. Bu değişiklik aynı zamanda, kentin toplam nüfusunda da belirgin bir düşüşe neden olmuştur. Günümüzde 116'ya inen cinsiyet oran1, süreç içindeki en düşük seviyesindedir (Şekil 2).

Kent nüfusunun il nüfusuna oranı oldukça dikkat çekici bir yapıya sahiptir. Bir Cumhuriyet kenti olan Tunceli, başlangıçtaki nüfusuyla il nüfusunun yalnızca \%1'ini oluştururken, 2000'li yıllara kadar il nüfusunun ancak \%25'ini meydana getirmektedir. 2015 yılında \%40'a ulaşan bu oran, hem il nüfusundaki hem de kent nüfusundaki artışın birbirine paralel seyretmesi ve durağanlığı nedeniyle bu oranın stabil kalmasına neden olmuştur (Tablo 2).

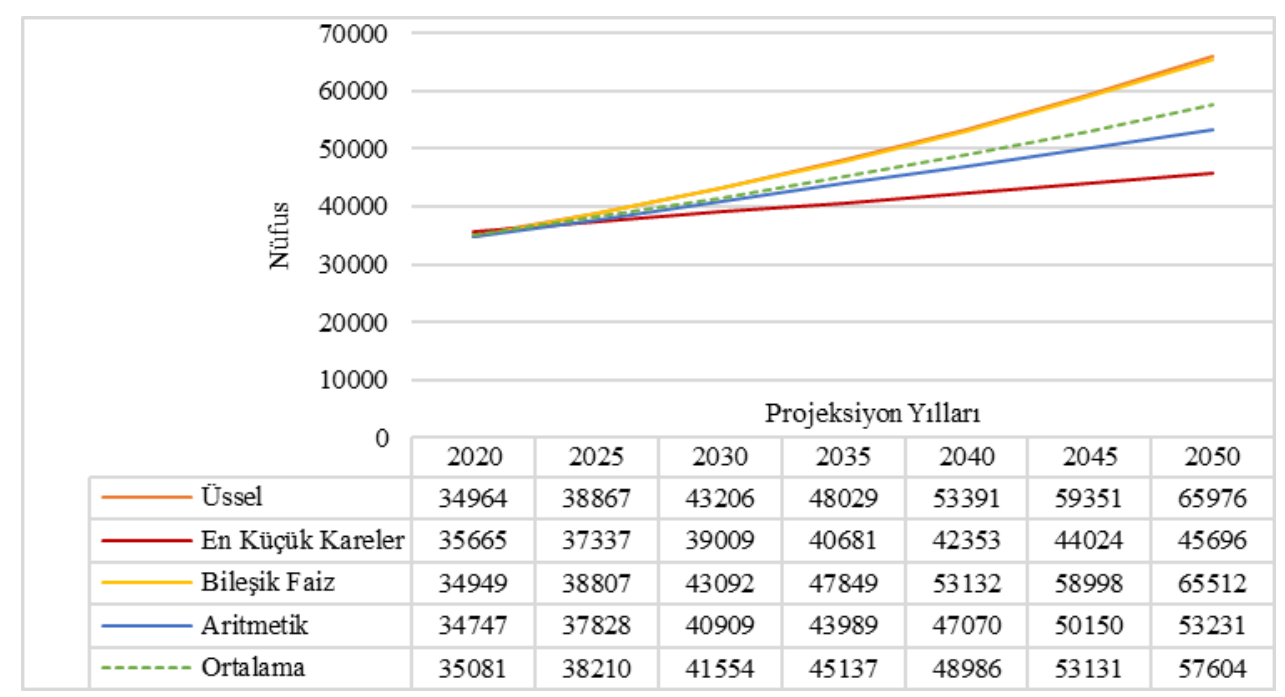

Şekil 3. Tunceli Kent Nüfusunun Projeksiyonu (2020-2050) 
Kent nüfusunun gelecekteki nüfusu, mevcut eğilime göre durağanlığını sürdürmektedir. Kentte 2020 yılında nüfusun ortalama 35 bin'e ulaşması beklenirken, 2030 yılında 41 bin'e ve 2050 yılında 57 bin'e ulaşması tahmin edilmektedir. Bu sonuçlardan en yüksek olanı 2050 y1lı itibariyle kent nüfusunun 66 bin civarında olacağını öngörmektedir (Şekil 3). Nüfusun gelişimi üzerinde doğumlar ve ölümler kadar göçler de önemli bir değişken olduğundan tahminlerde yanılma payı, her zaman söz konusudur Nitekim mevcut imar planı hazırlanırken ise 2040 yılında kent nüfusunun 75 bin olacağ kabul edilerek planlama yapılmıştır (Tunceli Belediyesi, 2018, s. 6).

\section{Nüfusun Yaş ve Cinsiyet Yapısı}

Bir yerin nüfus özellikleri içinde cinsiyet/yaş yapısının durumu nüfusun büyüklüğü kadar önemli bir değişkendir. Bu yapının mevcut durumu ve gelişim süreci üzerinde doğal değişimin yanında, göçler de belirleyici olmaktadır. Sonuçta cinsiyet/yaş yapısı, toplumsal ve iktisadi duruma etki etmekte ve böylece coğrafi görünüm üzerinde, belirleyici değişkenlerden biri haline gelmektedir (Canpolat, 2017, s. 125).

Nüfusun uzun yıllar içerisindeki yaş ve cinsiyet yapısı ile ilgili gelişim ve değişimini analitik olarak değerlendirme araçlarından biri olan nüfus piramidinin Tunceli kentindeki görünümü incelendiğinde 0-4 yaş grubundan 20-24 yaş grubuna kadarki tüm gruplarda, 1990 ile 2018 y1lları arasında önemli bir azalma olduğu görülmektedir. 0-4 yaş grubundan yukarı doğru genel olarak daha fazla belirginleşen bu azalma üzerinde doğum oranlarının düşmesinin yanında, özellikle eğitim amacıyla kentten ayrılan nüfusun artması da etkili olmaktadır (Şekil 4).

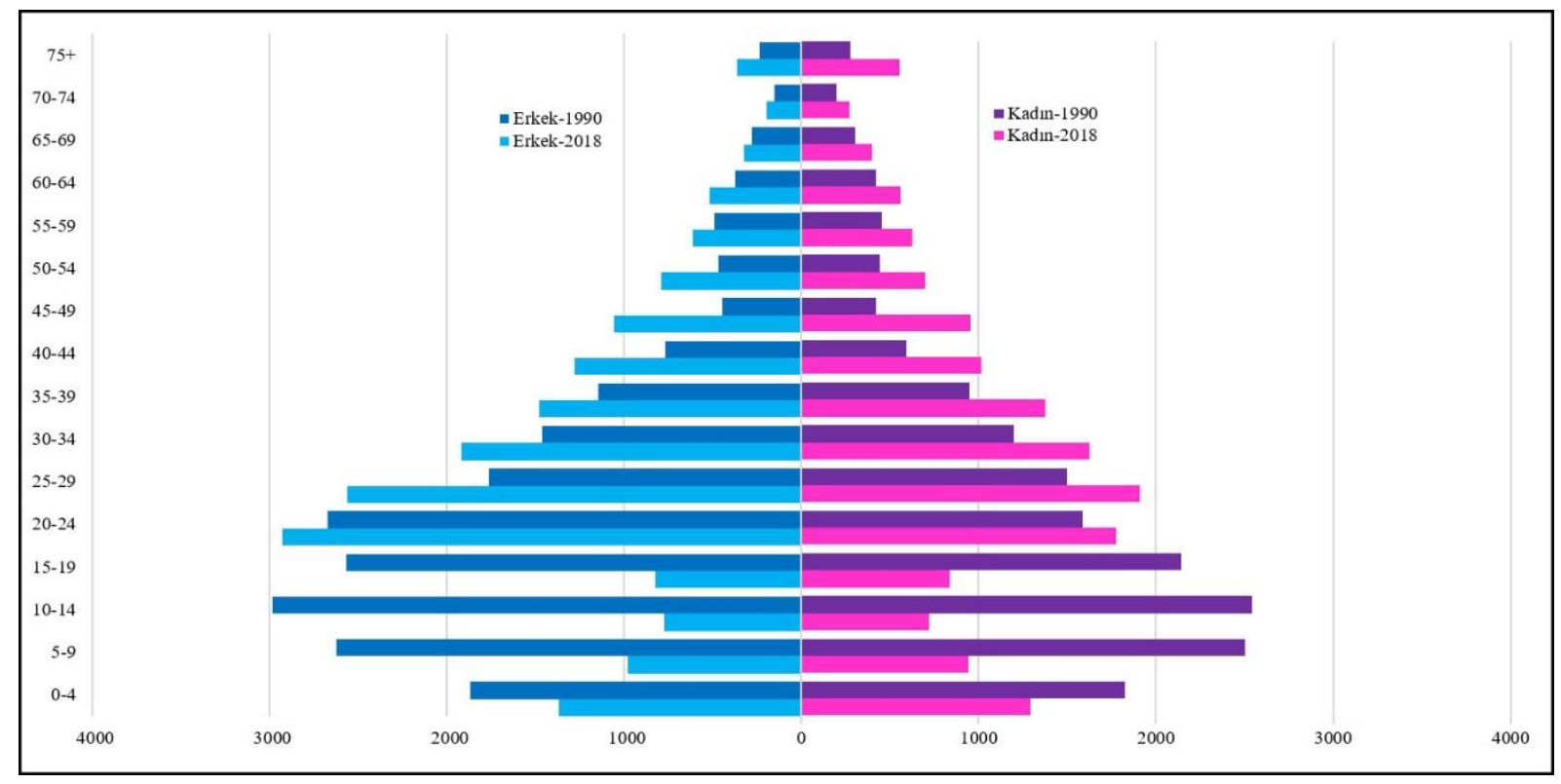

Şekil 4. Tunceli Kentinde Nüfusun Yaş ve Cinsiyet Yapısı (1990-2018 Yılları)

Nüfus piramidinde 20'li yaşlardan sonraki bütün yaş gruplarında 2018 yılı nüfusu, 1990 yılına göre daha fazladır. Bu fazlalık iş sahibi olma, eğitim ve evlenme gibi göç davranışı ihtimalini arttıran sebeplerin daha az etkili olduğu yaş grupları olması nedeniyledir. Yaş grupları içinde 25-34 yaş arası erkek nüfusta farkın diğerlerine göre daha yüksek olması, kentteki asker sayısı olmak üzere, buraya çalışmaya gelen devlet memurlarının etkisiyle gerçekleşmiştir (Şekil 4).

Kentteki nüfusun yaş ve cinsiyet yapısı ile il genelindeki yap1 arasında bariz bir benzerlik bulunmaktadır. Örneğin 0-4 yaş grubu ile 15-19 yaş grubu arasında kalan nüfusta 1990-2018 yılları arasında kentte olduğu gibi düşüş yaşanmış ancak bu düşüş kente nazaran çok daha fazla gerçekleşmiştir. Söz konusu farklılık üzerinde il genelinde, kırsal nüfustaki azalma önemli bir etken olarak belirtilebilir. 15-19 yaş grubundan sonra ise kent nüfusunda 2018 yılında bir artış gözlenirken il nüfusunda azalma yaşanması yine aynı faktörün etkisiyle gerçekleştiği söylenebilir. Piramitler arasındaki bir diğer önemli farklılık yetişkin ve yaşlı nüfus miktarında görülmektedir. Bu fark ilde tarım/ hayvancılık yapan ve göç etmeyen kırsal nüfusla ilgilidir (Şekil 5). 


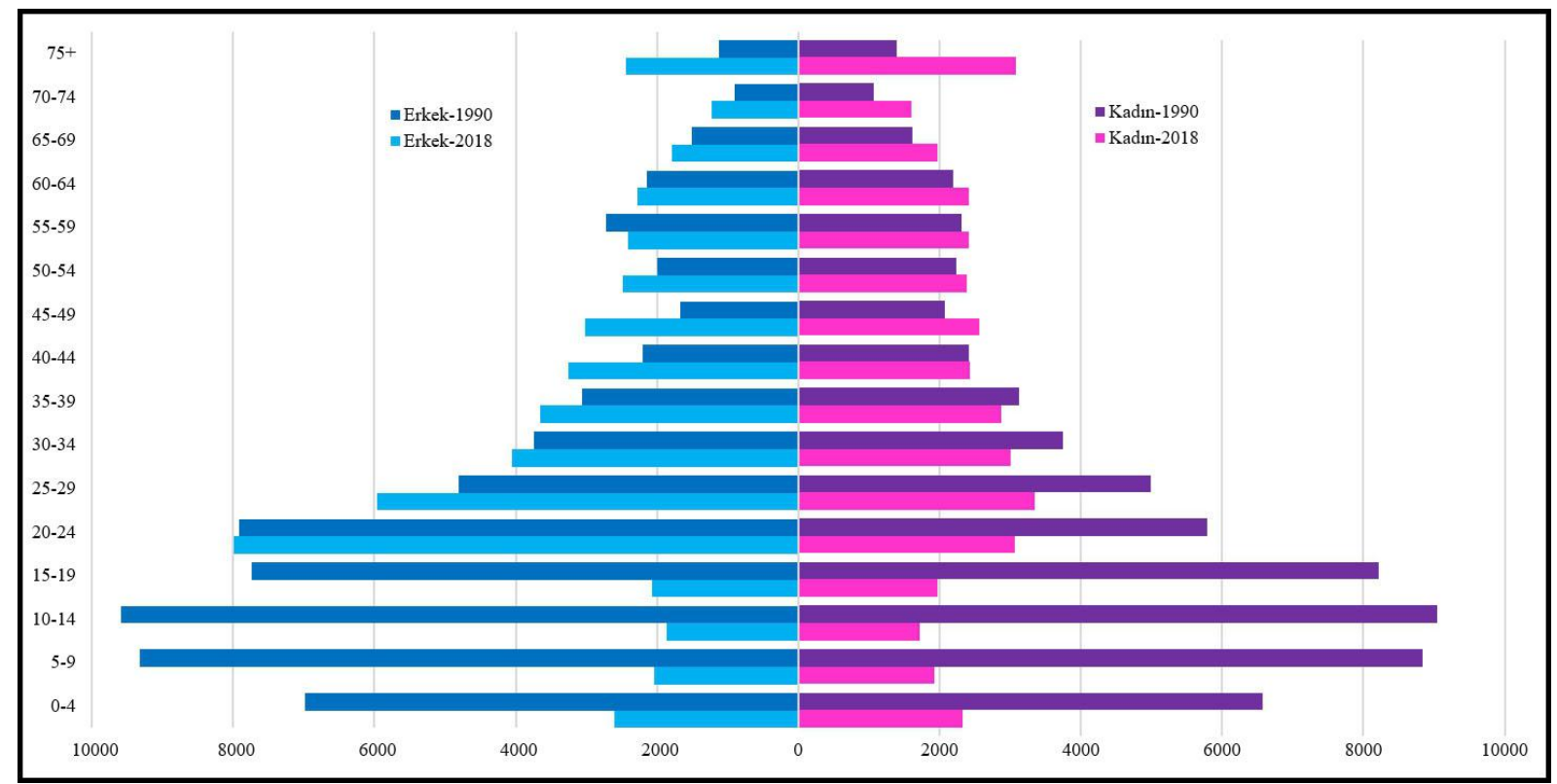

Şekil 5. Tunceli İlinde Nüfusun Yaş ve Cinsiyet Yapısı (1990-2018 Yılları)

Genel bir kabul olarak, birçok ülkede 15-64 yaş grubu içindeki nüfusa, çalışma çağındaki nüfus veya aktif nüfus denilmektedir. Faal ve faal olmayan nüfusun miktarı; toplam nüfusa, nüfusun yapısına, nüfus artışına, çalışma çağındaki nüfusa, göçe, şehirleşmeye ve eğitim seviyesine göre farklılıklar göstermektedir. Buna göre Tunceli kentinde nüfus geniş aralıklı olarak değerlendirildiğinde 0-14 yaş grubunun 2018 yılında, önceki sayıma göre oranı \%40'tan, \%17'ye gerilediği, 15-64 yaş grubunun ise $\% 62$ 'den $\% 77$ 'ye yükseldiği görülmektedir. 65 yaş üzeri nüfus ise $\% 4$ 'ten $\% 6$ 'ya yükselmiştir. Verilerden hareketle kentte bağımlı nüfus sayısı, \%72'den \%32'ye gerilediği görülmektedir (Tablo 3).

Tablo 3. Tunceli Kentinde Nüfusun Geniş Yaş Aralıklarına Bölünüşü ve Bağımlı Nüfus Oranı (19902018)

\begin{tabular}{|c|c|c|c|c|c|c|}
\hline Yaş Grubu & & & $\begin{array}{c}\text { Bağımlı Nüfus } \\
\text { Oranı }\end{array}$ & & & Bağımlı Nüfus Oranı \\
\hline $0-14$ & 14346 & $\% 40$ & \multirow{4}{*}{$\% 72$} & 6073 & $\% 17$ & \multirow{4}{*}{$\% 32$} \\
\hline $15-64$ & 21850 & $\% 62$ & & 25336 & $\% 77$ & \\
\hline $65+$ & 1447 & $\% 4$ & & 2106 & $\% 6$ & \\
\hline Toplam & \multicolumn{2}{|c|}{37643} & & \multicolumn{2}{|c|}{33515} & \\
\hline
\end{tabular}

Kaynak: TÜİK, Genel Nüfus Sayımı (1990), Nüfus İstatistikleri (2018)

Kentte nüfusun cinsiyet oranının sayım yıllarına göre gösterdiği büyük değişikliklerin mahalle bazında yansımalarına bakıldığında Askeri kurumların bulunduğu Atatürk ve Cumhuriyet Mahallelerinin özellikle 2000 yılında diğerlerinden ayrıldığg görülmektedir. Ancak günümüze doğru bu oran azalma göstermiş̧tir. Moğultay, İsmet İnönü ve Yeni Mahallelerinde ailelerin, yeni yapılan konutların bulunduğu Atatürk Mahallesi'ne doğru göç etmesi nedeniyle cinsiyet oranı artış göstermiştir. Aktuluk Mahallesinde de yeni açılan üniversitede çalışan nüfus içinde erkek nüfusun biraz daha fazla olması cinsiyet oranını arttırmıştır (Tablo 4). 
Tablo 4. Tunceli Kentinde Mahallelere Göre Kadın-Erkek Nüfusunun ve Cinsiyet Oranının Durumu (2000-2018)

\begin{tabular}{|c|c|c|c|c|c|c|c|c|c|}
\hline \multirow{2}{*}{ Mahalle } & \multicolumn{2}{|c|}{2000} & \multicolumn{2}{|c|}{2010} & \multicolumn{2}{|c|}{2018} & \multicolumn{3}{|c|}{ Cinsiyet Oranı } \\
\hline & Erkek & Kadın & Erkek & Kadın & Erkek & Kadın & 2000 & 2010 & 2018 \\
\hline Aktuluk* & 238 & 226 & 158 & 156 & 512 & 426 & 105 & 101 & 120 \\
\hline Alibaba & 1965 & 1797 & 1796 & 1528 & 1156 & 1079 & 109 & 118 & 107 \\
\hline Atatürk & 5019 & 2091 & 5164 & 4571 & 10605 & 8958 & 240 & 113 & 118 \\
\hline Cumhuriyet & 4030 & 3173 & 3287 & 2793 & 2634 & 2258 & 127 & 118 & 117 \\
\hline Esentepe & 761 & 767 & 840 & 685 & 520 & 498 & 99 & 123 & 104 \\
\hline İsmet İnönü & 163 & 159 & 190 & 163 & 508 & 550 & 103 & 117 & 92 \\
\hline Moğultay & 1833 & 1607 & 2154 & 1802 & 1598 & 1299 & 114 & 120 & 123 \\
\hline Yeni & 773 & 748 & 763 & 674 & 434 & 476 & 103 & 113 & 91 \\
\hline
\end{tabular}

* Aktuluk Mahallesi 2013 yılına kadar merkez ilçe sınırları içinde yer alan bir köydür.

Kaynak: TÜIK, Genel Nüfus Sayımı (2000), Nüfus İstatistikleri $(2010,2018)$

\section{Nüfus Hareketleri}

Nüfus hareketleri yaşamsal süreçleri (doğum ve ölüm) ile göç olaylarını kapsayan temel demografik konulardan biridir. Doğumlar ve ölümler ile birlikte doğum çağındaki kadın sayısı arasındaki bağlantı, gerçeğe en yakın nüfus artışı hakkında bilgi verir. Bu artış oranı ile gerçekleşen nüfus artış oranı arasındaki fark ise göçlere bağlı olarak meydana gelmektedir.

Tunceli'nin 2017 yılı itibariyle yalnızca doğum ve ölüm sayılarına bağlı olarak hesaplanan doğal nüfus artış oranı $\% 5$ olarak gerçekleşmiştir. 2016-2017 döneminde gerçekleşen nüfus artış oranı ise $\% 0,57$ 'dir. Dolayısıyla kentin nüfus tutma kapasitesi bakımından zayıf bir durumda bulunması, negatif göç hızını tetiklediği söylenebilir (Tablo 5).

Tablo 5. Tunceli Merkez İlçesinde Doğumlar, Ölümler ve Doğal Nüfus Artış Oranı (1990, 2000, 2017)

\begin{tabular}{cccccccc}
\hline Tunceli & $\begin{array}{c}\text { 15-49 Kadın } \\
\text { Nüfus }\end{array}$ & Toplam Nüfus & Doğum & Ölüm & $\begin{array}{c}\text { Genel Doğum } \\
\text { Oranı \%o }\end{array}$ & $\begin{array}{c}\text { Genel Ölüm Doğal Nüfus Artış } \\
\text { Oranı \%o }\end{array}$ & $\begin{array}{c}\text { Oranı \% } \\
\text { Oran }\end{array}$ \\
\hline 1990 & 8387 & 37643 & 602 & 34 & 71,8 & 0,9 & 7,1 \\
\hline 2000 & 7110 & 30323 & 375 & 28 & 52,7 & 0,9 & 5,2 \\
\hline 2017 & 9395 & 33046 & 527 & 187 & 56,1 & 5,7 & 5,0 \\
\hline
\end{tabular}

Kaynak: TÜIKK, Doğum İstatistikleri, Ölüm İstatistikleri, Nüfus İstatistikleri (1990, 2000, 2017)

Nüfus hareketlerinden göç, insanlık tarihiyle içi içe olan ve toplumsal değişiklikler içerisinde çok önemli bir yere sahip harekettir. Bu hareketin kaynağında çok çeşitli faktörler yer almakla beraber, ortaya çıkardığı sonuçlar itibariyle de hem toplumda hem de mekânda çok sayıda durumu etkileyen ve bu açıdan insanı ve mekânı açıklamada oldukça önemli olan bir faktördür.

Tunceli oldukça karmaşık bir göç aktivitesine sahiptir. Bir yandan nüfusa istihdam oluşturulamadığ1 için yurt içi ve yurt dışına yönelimler olmaktadır. Doğu bölgelerinde sınırlı olan iş olanaklarından faydalanamayan faal nüfus, iş olanaklarının görece fazla olduğu daha gelişmiş bölgelere ya da büyük kentlere göç etmektedir. Öte taraftan hala kırsal alandan yakın büyük şehirlere doğru (Elazığ, Malatya) olan nüfus hareketi devam etmektedir. Son 30 yılda bu göçlere güvenlik nedeni ile olan göçler de eklenmiştir. Köylerin boşalması, terör tehdidi ve can güvenliği farklı bir göç dalgasına sebep teşkil etmektedir (Solak, 2015, s. 86). 

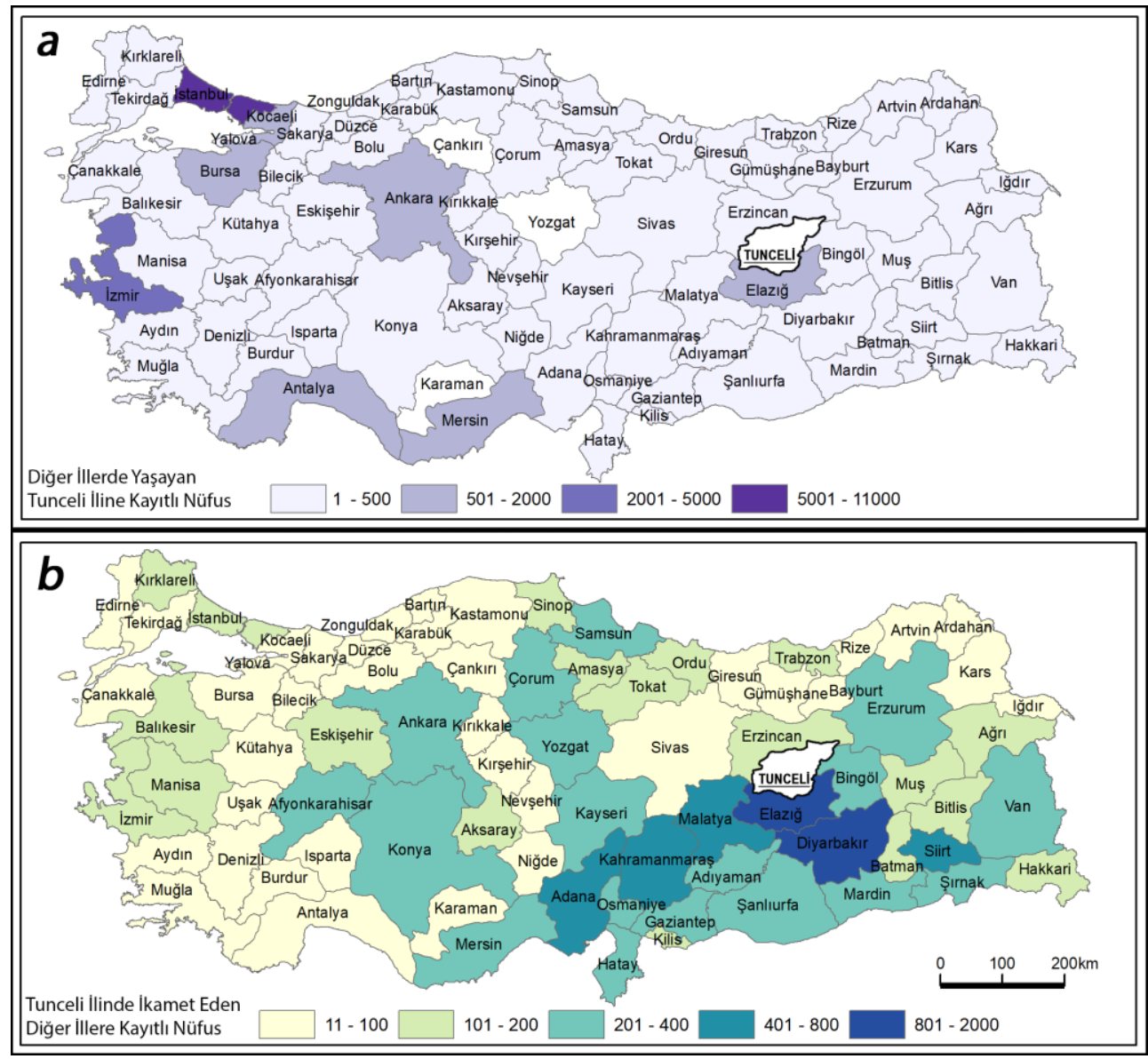

Şekil 6. Tunceli İlinin Doğum yerine ve İkamet Yerine Göre İller Bazında Dağılışı (2018)

Tunceli kent ölçeğinde göç ile ilgili veri bulunamadığından, dolaylı bir veri seti olarak doğum yerine ve ikamet yerine göre nüfusun illere dağılışı kullanılmıştır. Buradan hareketle Tunceli doğumlu olup diğer illerde ikamet eden nüfusun dağılışında en fazla yoğunluk İstanbul ve çevresi ile Ankara'da görülmektedir. Kıyıda yer alan İzmir, Antalya ve Mersin illeri ise ikinci bir küme olarak değerlendirmek mümkündür. Elazı̆̆ ilini yakınlığa ve kolay ulaşıma bağlı olarak, ayrı değerlendirilmesi gerekmektedir (Şekil 6-a).

Diğer illere kayıtlı nüfusun dağılışına bakıldığında, Elazığ ve Diyarbakır illerinin mesafenin ve kültürel bağların fazlalığı nedeniyle ilk sırada yer aldığı görülmektedir. Malatya, Kahramanmaraş, Adana ve Siirt illeri aldığı göç sayısı bakımından ikinci grubu oluşturmaktadır (Şekil 6-b).

2018 yılı itibariyle Tunceli merkez ilçesine kayıtlı nüfustan il dışında yaşayanların sayısı 24 bin civarında iken, diğer illerin nüfusuna kayıtlı olup Tunceli merkez ilçesinde ikamet eden nüfus miktarı 15 bin civarındadır. Buna göre mevcut merkez ilçe nüfusunun yaklaşık \%40’1 il dışından buraya gelen nüfustan oluşmaktadır (Şekil 6-b).

Tunceli'de göç edenlerin göç etme nedenleri ise sırasıyla geçim sıkıntısı, işsizlik, yerleşim alanlarının boşaltılması, eğitim olanaklarının zayıflığı, sağlık sorunları ve güvenlik nedenleridir (Solak, 2015, s. 137).

\section{Nüfusun Dağglışı}

Tunceli kenti, birbirinden belirgin eşiklerle ayrılmış beş bölümden oluşmaktadır. Kentin tarihi merkezinin de bulunduğu Munzur çayının kuzeyindeki ilk bölümü Cer Tepesi, Düldül Tepesi ve Zeytin Tepesi'nin yüksek eğimli yamaçları üzerinde kurulu olan ve artık gelişimi çok azalan bölümdür. Bu kesimde Alibaba, Moğultay, Yeni ve Esenkent Mahalleleri yer almaktadır. Gelişimin azalması üzerinde yüksek eğime bağlı yapılaşmanın oldukça zor olmasının yanında, ulaşımın zorluğu ve ekstrem yağışlarda gerçekleşen afetler belirleyici olmaktadır. Kentin ikinci bölümü Munzur çayının 
güneyindeki Bozkaya tepesinin güneydoğusundaki sırtı ve iki yamac1 üzerinde kurulu olan Cumhuriyet Mahallesi'dir. Kentin günümüzdeki gelişim alanını oluşturan Atatürk Mahallesi'nin yer aldığı üçüncü bölüm olan Sigank deresi ve kolları tarafından oluşturulan küçük bir birikinti konisinin Munzur suyunun oluşturduğu sekiyle birleştiği, Deribirik düzünün üzerinde az eğimli bir sahadır. $\mathrm{Bu}$ düzlüğün doğusunda ise topografik açıdan yerleşmeye elverişli olmayan aynı zamanda kentten, Uzunçayır Baraj Gölü’nün suları tarafından hidrografik olarak ayrılan, vadiler tarafından çok fazla parçalanmış bir alan yer almaktadır. Kentin dördüncü bölümü Atatürk Mahallesi'nden Abbas deresi vadisiyle ayrılan ve Rabat deresine kadar olan kesimi kapsayan Aktuluk Mahallesi'nin olduğu alandır. Kentin son bölümü ise Pülümür çayı vadisi içinde Erzincan-Tunceli karayolu üzerinde eğim ve engebenin kısmen izin verdiği bir kesimde yer alan İsmet İnönü Mahallesi’nin bulunduğu kesimdir (Şekil 1).

Tunceli kentinin 2700 hektara yakın arazisi bulunmaktadır. Ancak mahallelerin sınırları içinde kalan arazilerin bir bölümü eğim, arazinin parçalı yapısı, jeolojik riskler ve bitki örtüsü nedeniyle kullanım dışındadır. Dolayısıyla kent yerleşkesinin yüz ölçümü 2000 hektarın altındadır. Bu arazinin de 215 hektarı, imar planında kentsel gelişim alanı olarak görülmektedir. Mevcut yüz ölçümü ve nüfusa bağlı olarak kentin nüfus yoğunluğu 2018 y1lı itibariyle 12,6'dır (Tablo 6). Bu değer komşu kentlerdeki nüfus yoğunluğunu oldukça altındadır. Nitekim Elazığ'da 2018 yılı itibariyle yoğunluk değeri 58 iken, Erzincan'da ise 23'tür.

Mahallelere göre nüfus yoğunluğunda en yüksek değere Moğultay Mahallesi ulaşırken, en düşük değer 2013 yılında Munzur Üniversitesinin inşaatının tamamlanmasıyla kente bağlanan Aktuluk Mahallesi'dir (Tablo 6).

Tunceli kenti tek merkezli (monocentric) bir yapı göstermektedir. Bu merkezi iş sahasının bulunduğu Moğultay Mahallesi, resmi kurum binalarının da yer alması nedeniyle önemlidir. Mahallenin konut gelişim alanlarının bulunmaması nedeniyle, nüfus bakımından daha fazla büyümesi beklenmemektedir. Sadece kentsel yenilemeye bağl1 olarak bir değişiklik beklemek mümkündür. Ancak kentin iş-ticaret sahalarının Atatürk Mahallesi'ne doğru taşınmasına/büyümesine bağlı olarak Moğultay Mahallesi'nde bir büzüşme eğilimi görülmektedir. Son 17 yılda nüfusunun \% -11 oranında azalması bu olguyu doğrulamaktadır. Dolayısıyla kent çok merkezli (policentric) bir yapıya doğru evrilmektedir.

Tablo 6. Tunceli Kentinde Mahallelere Göre Nüfusun Dağılışı (2000-2010-2018)

\begin{tabular}{|c|c|c|c|c|c|c|c|}
\hline \multirow[b]{2}{*}{ Mahalle } & \multirow{2}{*}{$\begin{array}{c}\text { Yüz Ölçümüi } \\
\text { (Hektar) }\end{array}$} & \multicolumn{3}{|c|}{ Toplam Nüfus } & \multirow{2}{*}{$\begin{array}{c}\text { Nüfus Artış } \\
\text { Oranı } 2000-2018 \\
\%\end{array}$} & \multicolumn{2}{|c|}{ Nüfus Yoğunluğu } \\
\hline & & 2000 & 2010 & 2018 & & 2000 & 2018 \\
\hline Aktuluk* & 704,5 & 464 & 314 & 938 & 102 & 1 & 1,3 \\
\hline Alibaba & 60,5 & 3762 & 3324 & 2235 & -41 & 62 & 36,9 \\
\hline Atatürk & 919 & 7110 & 9735 & 19563 & 175 & 8 & 21,3 \\
\hline Cumhuriyet & 259 & 7203 & 6080 & 4892 & -32 & 28 & 18,9 \\
\hline Esentepe & 257 & 1528 & 1525 & 1018 & -33 & 6 & 4,0 \\
\hline İsmet İnönü & 348 & 322 & 353 & 1058 & 229 & 1 & 3,0 \\
\hline Moğultay & 59,4 & 3440 & 3956 & 2897 & -16 & 58 & 48,8 \\
\hline Yeni & 62 & 1521 & 1437 & 910 & -40 & 25 & 14,7 \\
\hline Toplam & 2669,4 & 25350 & 26724 & 33511 & 32 & 9 & 12,6 \\
\hline
\end{tabular}

Kaynak: TÜİK, Genel Nüfus Sayımı (2000), Nüfus İstatistikleri (2010-2018)

Alibaba, Yeni, Cumhuriyet ve Esentepe mahalleleri genel olarak eğim değerlerinin izin verdiği arazilerin büyük kısmının kullanıldığı yerlerdir. $\mathrm{Bu}$ mahallelerin bazı kesimlerinde ise eğim ve litolojiye bağlı olarak yapılaşma yasağı olan alanlar mevcuttur. Alibaba Mahallesi Munzur suyu vadisi ve gerisindeki eğimli arazi tarafında gelişimi sınırlandırılmış, merkezi iş sahasının bulunduğu Moğultay Mahallesi'ne yakınlığına bağlı olarak daha çok günübirlik ve periyodik ihtiyaçlara yönelik ticaretin geliştiği ancak nüfusun azalma eğiliminde olduğu bir mahalledir. Nitekim 2000-2017 yılları arasında nüfusunun 3'te birini kaybetmiştir. 
İsmet İnönü Mahallesi Pülümür çayının kuzey sahilinde yer alan ve organize sanayi bölgesinin 2001 yılında bitirilmesiyle oluşturulmuş bir mahalledir. İsmet İnönü Mahallesi 1980'den sonra gelişmeye başlamıştır. Kaçak yapılaşma problemi olan mahallenin nüfusu OSB'nin etkisiyle yaklaşık 3 kat artmıştır. OSB'nin aktif iş yeri sayısının artmasıyla birlikte mahallenin bu artış eğilimini sürdürmesi beklenebilir (Tablo 6, Şekil 7).

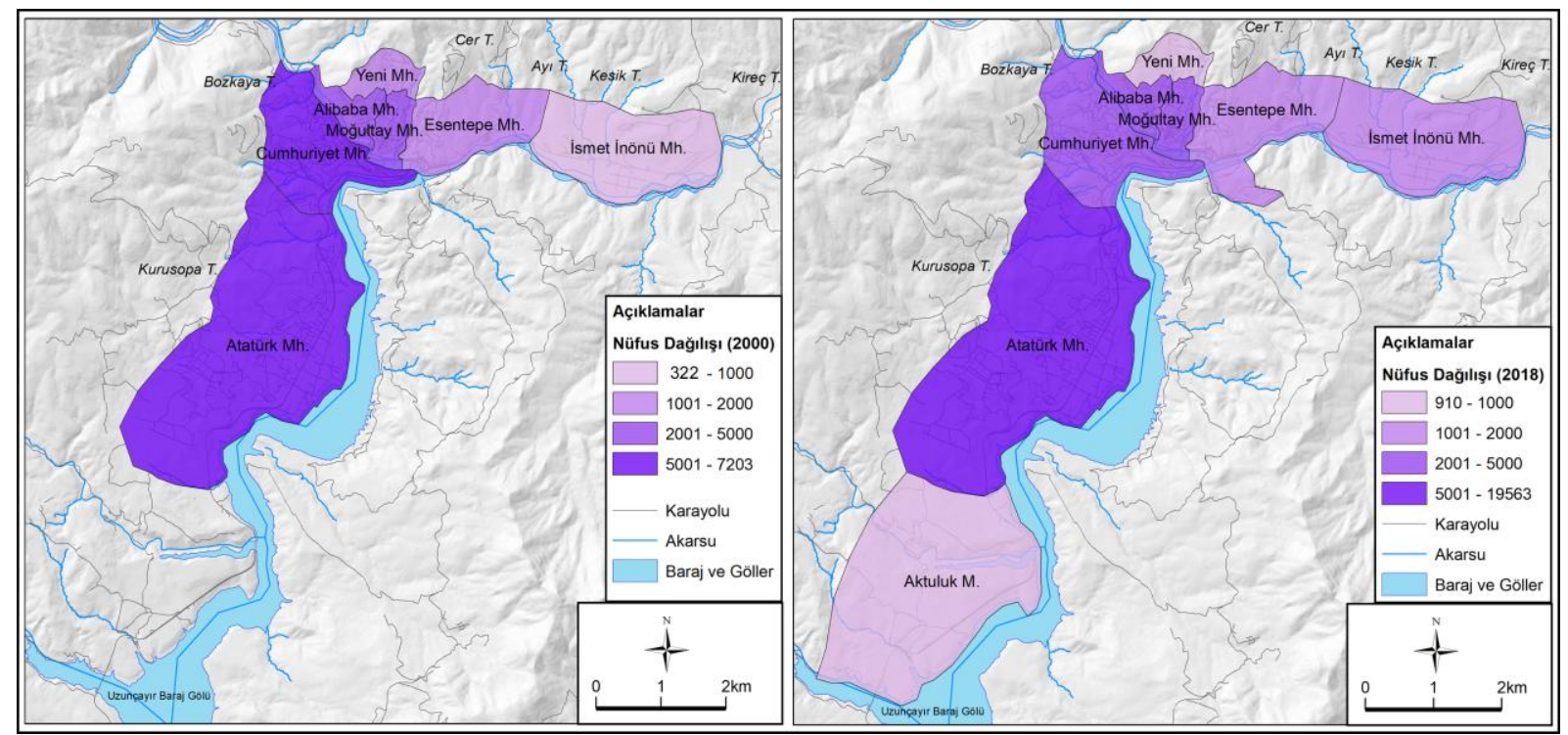

Şekil 7. Tunceli Kentinde Nüfusun Mahallelere Dağılışı (2000 ve 2018 Yılları)

Kentin en önemli gelişme aksı olan Tunceli-Elazığ karayolu üzerinde yer alan Atatürk ve Aktuluk Mahallesi, diğer mahallelere göre yapılaşmaya daha uygun arazilere sahip olması nedeniyle nüfus artışının en fazla yaşandığı yerlerdir. Aktuluk Mahallesi günümüzde yapılan konutlarla büyüme eğiliminde olan bir mahalledir. Nitekim kente bağlanmadan önce 300 civarında olan nüfusu 3 kattan fazla bir artı̧̧ göstermiştir (Tablo 6, Şekil 7).

Cumhuriyet Mahallesi şehir merkezinin bulunduğu kesime göre eğim değerlerinin nispeten azaldığı ve yapılaşmaya uygun arazinin daha fazla olduğu bir mahalledir. Bu nedenle resmi kurumlar dışında, çevre yolu üzerinde yer alan ticari alanların da etkisiyle Atatürk Mahallesi'nden sonra en fazla nüfusun bulunduğu mahalledir.

Nüfusun gelişimini ve dağılışını açıklamada mahalleler bazında konut ve işyeri sayılarındaki değişim değerlendirildiğinde nüfus artış oranları ile merkezi iş sahalarındaki farklılaşmanın paralel bir seyir izlediği görülmektedir. Mahallelere göre konut sayısında en belirgin değişim Atatürk ve İsmet İnönü mahallelerinde gerçekleşmiştir. Kentin birincil gelişim aksı üzerinde olan Atatürk Mahallesi'nin son 7 yılda yapılan yeni 4021 konut ile hızlı bir büyüme sürecinde olduğu görülmektedir. Cumhuriyet Mahallesi'nin çevre yolu üzerinde yapılan konutları, Esentepe Mahallesi'nin ise Batman köyü sınırları içinde yapılan toplu konutları yapılaşmayı hızlandırmıştır. Moğultay, Alibaba ve Yeni Mahallede konut gelişim alanlarının az olması ve engebelilik, konut sayısındaki değişimi yavaşlatmışıtır (Şekil 7).

İşyeri sayısı bakımından birincil merkezi iş sahası olan Moğultay Mahallesi ile ikincil iş merkezinin yer aldığı Atatürk Mahalleleri en fazla artışın yaşandığı yerlerdir. Alibaba Mahallesi'nde Ovacık karayolu üzerinde Munzur suyu yakınında açılan işyerleriyle az da olsa bir artış yaşanırken diğer mahallelerin hepsinde özel işyeri sayısının azalması, kent ekonomisi açısından önemli bir problem olarak görülmektedir. Söz konusu ekonomik daralma üzerinde kent nüfusunun artış hızının durağan olması ve kentin etki sahasındaki nüfusun azalması öncelikle etkili olmaktadır. Ayrıca kent içi ticaret alanlarının hareketi de işyeri sayısının değişimi üzerinde etkilidir (Tablo 7, Şekil 7). 
Tablo 7. Tunceli Kentinde Mahallelere Göre Konut ve Özel İşyeri Sayıları

\begin{tabular}{|c|c|c|c|c|c|c|}
\hline \multirow{2}{*}{ Mahalleler } & \multicolumn{2}{|c|}{ Konut Sayısı } & \multirow{2}{*}{ Fark } & \multicolumn{2}{|c|}{ Özel İşyeri Sayısı } & \multirow{2}{*}{ Fark } \\
\hline & 2011 & 2018 & & 2011 & 2018 & \\
\hline Aktuluk & - & 228 & - & - & 12 & - \\
\hline Alibaba & 1178 & 1303 & 125 & 8 & 17 & 9 \\
\hline Atatürk & 3023 & 7044 & 4021 & 34 & 475 & 441 \\
\hline Cumhuriyet & 2030 & 2435 & 405 & 190 & 115 & -75 \\
\hline Esentepe & 481 & 601 & 120 & 53 & 19 & -34 \\
\hline İsmet İnönü & 243 & 618 & 375 & 22 & 13 & -9 \\
\hline Moğultay & 1385 & 1493 & 108 & 370 & 964 & 594 \\
\hline Yeni & 456 & 467 & 11 & 8 & 4 & -4 \\
\hline Toplam & 8796 & 14189 & 5393 & 685 & 1619 & 934 \\
\hline
\end{tabular}

Kaynak: TÜiK, Konut ve İşyeri İstatistikleri $(2011,2018)$

Kentteki özel işyeri sayısının yaklaşık yarısı Ticaret ve Sanayi odasına (809) kayıtlıdır. Kalan diğer yarısı ise Esnaf ve Sanatkârlar odasına kayıtlı(842) işyerlerinden oluşmaktadır (Tunceli Esnaf ve Sanatkarlar Odası, 2018). Ancak Ticaret ve Sanayi odasına kayıtlı işyerlerinden 246'sı pasif durumdadir (Tablo 8).

Tablo 8. Tunceli Kentinde Ticaret ve Sanayi Odasına Kayıtlı İşyerleri Sayısı

\begin{tabular}{lcc}
\hline Şirket Tipi & Aktif & Pasif \\
\hline Anonim Şirketi & 56 & 8 \\
\hline Gerçek Kişi & 238 & 131 \\
\hline Kooperatif & 49 & 18 \\
\hline Limited Şirket & 220 & 89 \\
\hline Toplam & $\mathbf{5 6 3}$ & $\mathbf{2 4 6}$ \\
\hline
\end{tabular}

Kaynak: Tunceli Ticaret ve Sanayi Odası (2018)

Kentteki işyeri sayısındaki artış üzerinde 2009 yılında başlayan güvenlikle ilgili problemlerin azaltılması yönündeki değişikliklerin etkisiyle özellikle yurt dışında ve il dışında yaşayan Tuncelililerin kente yaptığı yatırımlar, belirleyici olmaktadır. Kentte inşaat ve turizm sektöründe ortaya çıkan hareketlilik, doğalgazın kente gelmesiyle açılan firmalar ile arazileri üzerinde konut+işyeri şeklinde oluşturulan yapılar ekonomik açıdan bir değişim yaşandığını göstermektedir.

\section{Nüfusun Sosyo-Ekonomik Yapısı}

Tunceli Osmanlı arka planı ve Cumhuriyetle devam eden gelişim sürecinde toplumsal ve siyasal muhalefetin merkezi kentlerinden birisi olmuştur (Solak, 2015, s. 84). Ayrıca tarihi faktörler, doğal ortam özelliklerinden kaynaklanan problemler, sosyal yapı ve yönetim politikaları kentin mevcut ekonomisi üzerinde oldukça belirgin etkilere sahiptir (Solak, 2015, s. 87). İl topraklarının büyük bir kesiminin dağlı olması, ulaşım imkânlarının zor olması, 1950'lere kadar Tunceli'nin çevre illerle olan ulaşımının çok sınırlı kalmasına ve uzun yıllar dışa kapalı ve durağan bir ekonomik yapının hâkim olmasına neden olmuştur. İl ekonomisi tümüyle tarıma dayanmakla birlikte ne bitkisel üretim ne de hayvancılık gelişkin değildir (Tunceli Belediyesi, 2017, s. 2). İl geneline hâkim olan ve kente de yansıyan ekonomik olarak az gelişmişlik durumu nedeniyle bağlı ilçelerine dahi, ticaret ve hizmet fonksiyonları açısından yetmeyen bir kent haline gelmiştir. Bu nedenle ilin ve kentin katma değer oluşturmakta sınırlı kalması, diğer şehir kasaba ve köyleri ekonomik açıdan Elazığ’a bağımlı hale getirmektedir (Solak, 2015, s. 86)

Tunceli kentinin ekonomisi üzerinde il genelindeki güvenlikle ilgili gelişmelerin etkisi çok fazladır. Kente yönelik olumsuz algıların kırılabilmesi için yapılan kamusal yatırımlar ve problemlerin giderilmesine yönelik çalışmalar, son yıllarda iktisadi faaliyetlerde bir hareketlilik oluşturduğu görülmektedir.

Kentte organize sanayi bölgesi kurulma aşamasında olduğu için ağır sanayi mevcut değildir. Organize sanayi bölgesinde 42 parselden 22 tanesi için ruhsat alınmıştır. Ruhsat alınan parseller de birkaç işletme dışında genel olarak pasif durumdadır. 
Nüfusun iktisadi faaliyet türlerine göre dağılımında en önemli husus kamuda çalışan sayısının fazlalığı nedeniyle hizmet sektörünün çok daha fazla çıkmasıdır. Dolayısıyla tarım ve sanayi sektöründe çalışan sayısı toplam $\% 10$ civarındadır. Bu oran kente yönelik güncel ekonomik faaliyet verisi olmamasına rağmen IŞSKUR'un il genelinde çıkardığı istatistiklerde de 2016 yılı itibariyle önemli bir değişim yaşanmadığını göstermektedir (İş̧ur İstatistikleri). Nitekim 2000 yılında 129 kişi imalat sanayinde çalışırken (Tablo 9), 2010 yılı itibariyle sanayi tesisi olarak nitelendirilen 10 kuruluşta 105 kişi çalıştı̆̆ belirtilmektedir (Akın, 2010, s. 50). Günümüzde ise et entegre tesisi (1), süt işleme tesisi(1), hazır yemek(1), paketleme, ambalaj(1), alüminyum doğrama(1), pvc (2), ve tekstil atölyeleri (2) olmak üzere toplam 10 sanayi tesisinde 400'e yakın işçi çalışmaktadır (Tunceli TSO, 2018).

Mahalle bazında en fazla çalışan sayısı 4.komando tugayı, jandarma komutanlığı ve askeri lojmanların yer aldığı Atatürk Mahallesi'ndedir. Cumhuriyet Mahallesi'nde ise yine askeri alan dışında yer alan kamu kurum ve kuruluşları ile ticari alanların mevcudiyeti çalışan sayısını arttırmıştır (Tablo 9).

Tablo 9. Tunceli Kentinde Mahallelere Göre Nüfusun İktisadi Faaliyetlere Dağılımı (2000)

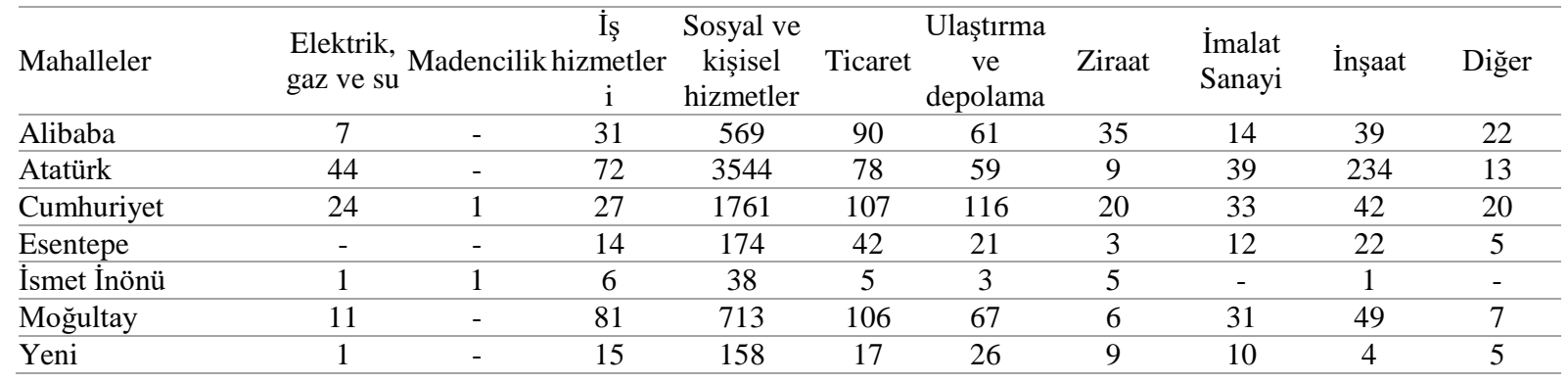

Kaynak: TÜiK, Genel Nüfus Sayımları, Ekonomik Nitelikler (2000)

Kentte iş imkânlarının kısıtlı olması göç olgusunu teşvik ettiği gibi eğitime verilen önemi de arttırmıştır. Dolayısıyla lise mezunu nüfusun \%33, lisans ve lisansüstü mezun sayısının \%29 olması nüfusun eğitim seviyesinin yüksek olduğunu göstermektedir. Mahalle ölçeğinde Atatürk Mahallesi'nde lisansüstü kademede olan nüfusun fazla olması Munzur Üniversitesi'nde çalışan öğretim görevlilerinin burada ikamet etmesi ile ilgili olduğu söylenebilir (Tablo 10).

Tablo 10. Tunceli Kentinde 6 yaş ve üzeri Nüfusun Eğitim Kademelerine ve Mahallelere Göre Bölünüşü (2017)

\begin{tabular}{lcccccccc}
\hline Eğitim Seviyesi & Alibaba & Atatürk & Cumhuriyet & Esentepe & İsmet İnönü & Moğultay & Yeni & Aktuluk \\
\hline Okur Yazar Değil & 121 & 240 & 227 & 75 & 79 & 88 & 79 & 41 \\
\hline Okur Yazar/İlkokul & 561 & 2494 & 976 & 236 & 252 & 552 & 232 & 74 \\
\hline İlköğretim/Ortaokul & 491 & 2458 & 942 & 241 & 271 & 431 & 214 & 58 \\
\hline Lise ve Dengi & 648 & 5466 & 1313 & 325 & 219 & 890 & 247 & 756 \\
\hline Önlisans/Lisans & 406 & 5232 & 854 & 172 & 78 & 784 & 138 & 94 \\
\hline Lisansüstü & 27 & 499 & 57 & 0 & 0 & 81 & 0 & 21 \\
\hline Bilinmeyen & 25 & 88 & 40 & 15 & & 26 & & \\
\hline Toplam & 2279 & 16477 & 4409 & 1064 & 899 & 2852 & 910 & 1044 \\
\hline
\end{tabular}

Kaynak: TÜiK, Eğitim İstatistikleri (2017).

Kentte Munzur Üniversitesi 2013 yılında açılmış ve 2014-2015 yılında öğrenci alımı yapılmıştır. İlk yılında toplam 2728'i ön lisans geri kalanı lisans ve lisansüstü olmak üzere toplam 7063 ögrenci öğrenim görürken ve 2017-2018 öğretim yılı itibariyle 5120 ön lisans, 6166 lisans, 720 yüksek lisans ve 14 doktora olmak üzere toplam 12020 öğrenciye yükselmiştir. Üniversitede 2014 yılında 288 öğretim görevlisi çalışırken, 2018 yılı itibariyle bu sayı 437'ye yükselmiştir (YÖK, 2018). Yeni kurulan bir üniversite olması dolayısıyla yeni açılacak bölümler ve akademik kadrolardaki büyüme ile üniversitenin kente olan katkısını arttıracağı söylenebilir.

Tunceli'de 14 özel eğitim kurumu bulunmaktadır. Bunlar içinde ilkokul, ortaokul ve lise kademesinde birer tane olmak üzere geri kalanları kurs ve eğitim merkezi olan kurumlardır. Kentte 2002 yılından 2018 yılına kadarki dönemde eğitim kademelerine göre hepsinde okul, derslik ve öğretmen sayıları 
artmakla birlikte anaokulu hariç diğer kademelerde öğrenci sayısı azalmıştır. Öğrenci sayısının azalması doğal nüfus artış hızındaki azalmayla ve göçle doğrudan ilgilidir (Tablo 11).

Tablo 11. Tunceli Kentinde Eğitim Kademelerine Göre Genel Yapı (2002-2018)

\begin{tabular}{lccccccc}
\hline \multirow{2}{*}{ Ĕ̆itim Kademesi } & \multicolumn{2}{c}{ Anaokulu } & \multicolumn{2}{c}{ Illköğretim } & \multicolumn{2}{c}{ Lise } \\
\cline { 2 - 8 } & $\mathbf{2 0 0 2}$ & $\mathbf{2 0 1 8}$ & $\mathbf{2 0 0 2}$ & $\mathbf{2 0 1 8}$ & $\mathbf{2 0 0 2}$ & $\mathbf{2 0 1 8}$ \\
\hline Okul & 1 & 4 & 11 & 14 & 7 & 10 \\
\hline Öğrenci & 53 & 580 & 3952 & 2815 & 2211 & 1656 \\
\hline Öğretmen & 2 & 35 & - & 254 & - & 212 \\
\hline Derslik & 5 & 24 & 158 & 199 & 97 & 137
\end{tabular}

Kaynak: Tunceli İl Milli Eğitim Müdürlüğü (2018)

Medeni durum yapısı altında evli sayısında genel olarak durağan bir artış eğilimi söz konusudur. Kentte hiç evlenmeyenlerin cinsiyet bazında farkın büyüklüğü dikkate alındığında sahada güvenlik görevlisi sayısının ve diğer kamu personellerinin sayısının fazlalığı hakkında yorum yapılabilir. Nitekim 2010 yılında hiç evlenmeyen erkek sayısının bir anda 5319 kişilik azalması ve 2011 yılında tekrar 5510 kişilik artış göstermesi bununla ilgilidir. Benzer şekilde evli erkek ve evli kadın sayısı arasındaki fark sahada çalışan evli erkek nüfustan ailesi burada olmayanların fazla olduğunu göstermektedir. Ancak bu fark son 10 yılda oldukça azalmıştır (Tablo 12).

Medeni durumda yıllara göre belirgin bir şekilde artan boşanan çift sayısı, Türkiye genelinde olduğu gibi Tunceli kentinde de önemli bir toplumsal problem olarak belirtilebilir. Nitekim son 10 yilda boşanan sayıs1 441 'den 1225 'e yükselmiştir. Bu sayıya boşandıktan sonra kenti terk eden bilhassa erkek nüfus dâhil edildiğinde daha da yükselmektedir. Dul sayısı ise kadınlarda ortalama yaşam süresinin uzunluğunun etkisiyle daha fazla olmak üzere, 770'ten 1002'ye yükselmiştir (Tablo 12).

Tablo 12. Tunceli Kentinde Nüfusun Medeni Durumu (2008-2018)

\begin{tabular}{ccccccccc}
\hline & \multicolumn{2}{c}{ Evli } & \multicolumn{2}{c}{ Hiç Evlenmedi } & \multicolumn{2}{c}{ Boşandı } & \multicolumn{2}{c}{ Dul } \\
\cline { 2 - 10 } Yıllar & Erk. & Kad. & Erk. & Kad. & Erk. & Kad. & Erk. & Kad. \\
\hline 2008 & 6073 & 5511 & 8132 & 2556 & 203 & 238 & 123 & 647 \\
\hline 2009 & 6465 & 5613 & 10550 & 2516 & 253 & 257 & 139 & 681 \\
\hline 2010 & 5976 & 5778 & 5231 & 2954 & 243 & 298 & 131 & 702 \\
\hline 2011 & 6506 & 5875 & 10741 & 3207 & 271 & 326 & 142 & 731 \\
\hline 2012 & 6540 & 6039 & 8969 & 3265 & 283 & 371 & 148 & 742 \\
\hline 2013 & 6819 & 6454 & 7034 & 3604 & 296 & 399 & 149 & 804 \\
\hline 2014 & 7490 & 7001 & 7108 & 4027 & 335 & 434 & 142 & 825 \\
\hline 2015 & 7536 & 7163 & 7869 & 4119 & 370 & 479 & 143 & 830 \\
\hline 2016 & 7423 & 7082 & 6723 & 3967 & 428 & 540 & 143 & 831 \\
\hline 2017 & 7435 & 7164 & 6774 & 3793 & 494 & 614 & 141 & 835 \\
\hline 2018 & 7574 & 7356 & 6552 & 3652 & 526 & 699 & 146 & 856 \\
\hline $\begin{array}{l}\mathbf{2 0 0 0 - 2 0 1 8} \\
\text { Değişim \% }\end{array}$ & $\mathbf{2 5}$ & $\mathbf{3 3}$ & $\mathbf{- 1 9}$ & $\mathbf{4 3}$ & $\mathbf{1 5 9}$ & $\mathbf{1 9 4}$ & $\mathbf{1 9}$ & $\mathbf{3 2}$ \\
\hline
\end{tabular}

Kaynak: TÜİK, Medeni Durum İstatistikleri (2008, 2018)

Kentte hane halkı sayısı 2000-2017 yılları arasında iki kata yakın artış gösterirken yerleşik nüfusta aynı oranda artış yaşanmaması, ortalama hane halkı büyüklüğüne yansımış ve 4,8'den 3,5'e gerilemiştir. Bu olgu üzerinde kentte ikamet eden kamu personellerinin etkisi önemlidir. Doğal nüfus artış hızındaki düşüşe ve kent dışına gerçekleşen göçün etkisiyle ortaya çıkan bu küçülme ülke genelindeki eğilime benzemektedir. Nitekim ülke geneli kentlerde 2000 y1lı ortalama hane halk1 büyüklüğü, 4,1 iken 2017 yılında 3,4'ün altına inmiştir (Tablo 13).

Mahalle bazında 2000 yılında en fazla hane halkının bulunduğu Cumhuriyet, Yeni ve Alibaba mahallelerinin 2017 yılına kadar ki süreçte, değerleri neredeyse hiç değişmemiştir. Yerleşik nüfusta ise çok belirgin bir şekilde azalma yaşanmıştır. Dolayısıyla ortalama hane halkı büyüklüğünün en fazla azaldığı mahalleler olmuştur. Atatürk Mahallesi'nde hane halkı sayısı 5 kat, yerleşik nüfus ise 4,3 kat artış göstermiştir. Ancak yerleşik nüfustaki artış daha düşük kaldığı için ortalama hane halkı büyüklüğü düşüş göstermiştir. Kentte genel olarak bakıldığında iki kata yakın hane halkı sayısında 
artış görülürken, yerleşik nüfusun 1,5 kat artış göstermesi nedeniyle ortalama hane halk1 büyüklüğünde azalma meydana gelmiştir (Tablo 13).

Tablo 13. Tunceli Kentinde Mahallelere Göre Hane Halkı ve Yerleşik Nüfus Sayıları ile Ortalama Hane halkı Büyüklükleri (2000-2017)

\begin{tabular}{|c|c|c|c|c|c|c|}
\hline \multirow[t]{2}{*}{ Mahalleler } & \multicolumn{2}{|c|}{ Hane Halkı Sayısı } & \multicolumn{2}{|c|}{ Yerleşik Nüfus } & \multicolumn{2}{|c|}{$\begin{array}{c}\text { Ortalama Hane Halkı } \\
\text { Büyüklüğü }\end{array}$} \\
\hline & 2000 & 2017 & 2000 & 2017 & 2000 & 2017 \\
\hline Aktuluk & - & 149 & - & 1085 & - & 7,3 \\
\hline Alibaba & 860 & 862 & 4118 & 2473 & 4,8 & 2,9 \\
\hline Atatürk & 963 & 4836 & 4229 & 18523 & 4,4 & 3,8 \\
\hline Cumhuriyet & 1507 & 1536 & 7110 & 4786 & 4,7 & 3,1 \\
\hline Esentepe & 345 & 417 & 1679 & 1151 & 4,9 & 2,8 \\
\hline İsmet İnönü & 78 & 402 & 401 & 987 & 5,1 & 2,5 \\
\hline Moğultay & 786 & 1002 & 3341 & 3064 & 4,3 & 3,1 \\
\hline Yeni & 349 & 336 & 1832 & 972 & 5,2 & 2,9 \\
\hline Toplam & 4888 & 9540 & 22710 & 33041 & 4,8 & 3,5 \\
\hline
\end{tabular}

Kaynak: TÜiK, Sosyal ve Demografik Nitelikler (2000) ve Nüfus İstatistikleri (2017)

Şehrin sağlık fonksiyonları açısından görünümüne bakıldığında, 2013 yılında yeni hizmet binasına taşınan Tunceli devlet hastanesinin 20 polikliniği ve 51 doktoruyla hizmet verdiği görülmektedir. Ayrıca kentte 5 aile sağlığı merkezi yardımcı sağlık hizmetleri vermektedir.

Tunceli'de vatandaşlar sağlık ihtiyaçlarının önemli bir bölümünü özellikle Elazığ'dan gidermektedir. Vatandaşlarda Tunceli hastanelerinin tam teşekküllü olmadığı yönünde bir algı bulunmaktadır. $\mathrm{Bu}$ alanda yeterli imkâna sahip Tuncelililer dahi büyükşehirler başta olmak üzere başka illere yatırım yapmaktadır. Kendi halkı dâhil özel teşebbüsün ilde yatırım yapmama düşüncesi bazı hizmetlerde rekabeti engellemekte ve kamu kurumlarından beklentileri de yükseltmektedir (Solak, 2015, s. 167).

\section{SONUÇ}

Dinamik yapısı nedeniyle değişim hızının fazla olduğu kentlerin demografik yapısı da bu değişimin en önemli bileşenidir. Tunceli'nin bir mahalle olarak baştan inşa edilmesinden orta ölçekli bir kente dönüşme süreci, nüfusun değişimiyle doğrudan ilişkilidir. Ancak bu nüfusun değişimi ve bileşenleri üzerinde kentin konumu, sosyokültürel yapısı, tarihsel süreç içinde meydana gelen olaylar ve devletin müdahaleleri oldukça belirleyici olmuştur. Bu nedenle Tunceli kenti de, demografik yapısı da kendine özgü yapıda olan bir yerleşmedir.

Tunceli'de kentin gelişiminde görülen durağanlık üzerinde hem beşeri yapıdan hem de doğal ortamdan kaynaklı birtakım sorunlar bulunmaktadır. Bu sorunlar arasında:

- Kentin tarihsel bir arka planının olmayışı,

- Ulaşım bakımından bir kesişim noktasında olsa da, topografik koşulların etkisiyle ulaşım fonksiyonunun fazla gelişmemiş olması,

- Konumu nedeniyle yalıtılmış yapısının olması,

- İdari açıdan bağlı yerleşmeleri için bile merkezi yer özelliğinin zayıf olması yani etki sahasının darlığı,

- Ekonomik faaliyetlerinin kısıtlı olması nedeniyle nüfusunu tutma kapasitesinin düşük olması,

- Kamusal yatırımların azlığı ve özel sektörün gelişmemiş olmasına bağlı istihdam olanaklarının k1sitli olmas1,

- Sosyo-kültürel yapıya bağlı dışlanmışlık hissi ile birlikte kente ve kent insanına yönelik önyargıların olması,

- Kentin fonksiyonel arazi kullanımında birbirinden kopuk ve uzak arazilerin varlığı yani kentin sıkışık bir alanda olsa bile kompakt bir yapı gösterememesi belirtilebilir. 
Mevcut duruma bakarak kuruluşundan günümüze sosyal, iktisadi ve kültürel olarak kentin ve dolayısıyla ildeki yaşanan problemlerin giderilmesi yönündeki kamusal çabaların, kente orta ve uzun vadede önemli katkılar sağlayacağı düşünülmektedir.

\section{KAYNAKÇA}

Akın, M. (2010). Kentin bugünü: ekonomik, siyasal ve demografik görünüm. Herkesin bildiği sır Dersim: tarih, toplum, ekonomi, dil ve kültür. (Aslan, Ş., ed.). 49-64. İstanbul: İletişim.

Canpolat, F.A. (2017). Pınarbaşı ilçesinin (Kayseri) beşeri ve iktisadi coğrafyası. Yayımlanmamış doktora tezi, Fırat Üniversitesi, Elazı $\breve{g}$.

Devlet Planlama Teşkilatı (2004). İlçelerin sosyo-ekonomik gelişmişlik sıralaması araştırması. 10 Aralık 2018 tarihinde www3.kalkinma.gov.tr/DocObjects/Download/8142/ilce.pdf, adresinden erișildi.

Newbold, K. B. (2014). Population geography: tools and issues. ABD: Rowman \& Littlefield.

Solak, A. (Ed.) (2015). Tunceli ili sosyal analiz çalışması. Ankara: Hegem.

Strateji ve Bütçe Başkanlığı (2018). Yıllar itibarıyla kalkınmada öncelikli yöreler. 20 Aralık 2018 tarihinde

http://www3.kalkinma.gov.tr/PortalDesign/PortalControls/WebIcerikGosterim.aspx?Enc=83D5 A6FF03C7B4FC0B6C445B8568FF66, adresinden erișildi.

Şaşmaz, M. (2014). Türkiye idari taksimatı ansiklopedisi (1920-2013) XIV.Cilt. Ankara: Türk Tarih Kurumu.

Timor, A. (1997). Orta büyüklükteki şehirler ve taşıdıkları önem. Ístanbul Üniversitesi Coğrafya Bölümü Dergisi, (5): 83-103.

Towfighi, P. S. (1970). The strategy of concentrated decentralization for regional growth. Yayımlanmamıs doktora tezi, Massachusetts Institute of Technology University, ABD. 5 Mart 2019 tarihinde https://dspace.mit.edu/handle/1721.1/78228\#files-area adresinden erişildi.

Tuncel, M. (2012). Tunceli. TDV İslâm Ansiklopedisi (DİA) içinde (c. 41, ss.378-380). İstanbul: Diyanet Vakfı Yayınları. 20 Ocak 2019 tarihinde https://islamansiklopedisi.org.tr/tunceli\#1, adresinden erişildi.

Tunceli Belediyesi. (2017). Tunceli ilave-revizyon nazım ve uygulama imar planı plan açıklama raporu. Tunceli: Tunceli Belediyesi.

Tunceli İl Milli Eğitim Müdürlügü (2018). Brifing raporu, Tunceli: Tunceli İl Milli Eğitim Müdürlüğü.

Tunceli Esnaf ve Sanatkarlar Odası (2018). Brifing raporu. Tunceli: Tunceli Esnaf ve Sanatklarlar Odas1.

Tunceli Ticaret ve Sanayi Odası (2018). Brifing raporu. Tunceli: Tunceli Ticaret ve Sanayi Odası.

TÜIK. (1940-2000). Genel Nüfus Sayımları. 20 Aralı 2018 tarihinde https://biruni.tuik.gov.tr/nufusapp/idari.zul, adresinden erişildi.

TÜIK. (1990-2000). Ekonomik Nitelikler. 20 Aralık 2018 tarihinde https://biruni.tuik.gov.tr/nufusapp/idari.zul adresinden erişildi.

TÜIK. (1990-2000). Sosyal ve Demografik Nitelikler. 20 Aralı 2018 tarihinde https://biruni.tuik.gov.tr/nufusapp/idari.zul, adresinden erişildi.

TÜIK. (2000-2017). Nüfus İstatistikleri. $15 \quad$ Şubat 2019 tarihinde https://biruni.tuik.gov.tr/medas/?kn=95\&locale=tr, adresinden erişildi.

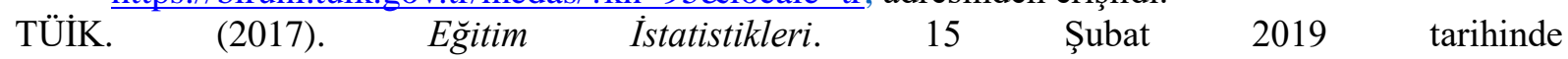
https://biruni.tuik.gov.tr/nufusapp/idari.zul, adresinden erişildi.

TÜIK. $\begin{array}{llllll} & \text { (2018). Doğum İstatistikleri. } & 15 & \text { Şubat } & 2019 & \text { tarihinde }\end{array}$ https://biruni.tuik.gov.tr/nufusapp/idari.zul adresinden erişildi.

TÜIK. (2018). Medeni Durum Istatistikleri. $15 \quad$ Şubat 2019 tarihinde https://biruni.tuik.gov.tr/nufusapp/idari.zul, adresinden erişildi.

TÜİK. (2018). Ölüm İstatistikleri. 15 Şubat 2019 tarihinde https://biruni.tuik.gov.tr/nufusapp/idari.zul, adresinden erişildi.

YÖK. (2018). Yüksek Öğretim Bilgi Yönetim Sistemi. $20 \quad$ Şubat 2018 tarihinde https://istatistik.yok.gov.tr/ adresinden erişildi. 